\title{
Introduction: Russia as a Great Power in Europe
}

I. For English-language coverage of the debates on Peter, see Paul Bushkovitch, Peter the Great, 2d ed. (Lanham, MD: Rowman and Littlefield, 2016); James Cracraft, Revolution of Peter the Great (Cambridge, MA: Harvard University Press, 2006); Lindsey Hughes, Russia in the Age of Peter the Great (New Haven, CT: Yale University Press, 2000).

2. David A. Bell, The First Total War (New York: Houghton Mifflin Harcourt, 2007), I-I7.

3. For synthesis of the research on social categories and service obligations, see Elise Kimerling Wirtschafter, Social Identity in Imperial Russia (DeKalb: Northern Illinois University Press, 1997).

4. Elise Kimerling Wirtschafter, "Military Service and the Russian Social Order," in Fighting for a Living: A Comparative History of Military Labour I50o-20oo, ed. Erik-Jan Zürcher (Amsterdam: University of Amsterdam Press, 2013), 394-95; William C. Fuller, Jr., Strategy and Power in Russia, I600-19I4 (New York: The Free Press, 1992), 45-46; Janet M. Hartley, Russia, I762-1825: Military Power, the State, and the People (Westport, CT: Praeger, 2008), 8-II; Elise Kimerling Wirtschafter, From Serf to Russian Soldier (Princeton, NJ: Princeton University Press, 1990), 3.

5. According to information from 1827 , in the central Russian province of Tver, a peacetime regiment could march 100 to IIo versts ( $\mathrm{I}$ versta $=\mathrm{I} .06$ kilometers) in six to eight days. Wirtschafter, Russian Soldier, 8I.

6. Quoted in Wirtschafter, Russian Soldier, 72.

7. Dominic Lieven, Russia against Napoleon: The True Story of the Campaigns of War and Peace (New York: Penguin Books, 2009).

8. On Russia's peacetime army, see Wirtschafter, Russian Soldier. For broad treatment, see John L. H. Keep, Soldiers of the Tsar: Army and Society in Russia, 1462-1874 (New York: Oxford University Press, 1985).

9. The discussion of Russian military history and empire building draws from my earlier works cited above and from Elise Kimerling Wirtschafter, Russia's Age of Serfdom 1649-186I (Malden, MA: Blackwell Publishing, 2008).

I0. Fuller, Strategy and Power, I-2 I; J. T. Kotilaine, "Opening a Window on Europe: Foreign Trade and Military Conquest on Russia's Western Border in the Seventeenth Century," Jahrbücher für Geschichte Osteuropas 46 (1998): 494-530.

II. Fuller, Strategy and Power, I4-34. 
I2. Fuller, Strategy and Power, 37-44; Hughes, Peter the Great, 92-98, 174-76.

13. Fuller, Strategy and Power, 34, 38-84.

14. Wirtschafter, Age of Serfdom, 108-9.

I5. On relations with the steppe peoples, see Andreas Kappeler, The Russian Empire: A Multiethnic History, trans. Alfred Clayton (Harlow, Eng.: Pearson, 200I); Michael Khodarkovsky, Russia's Steppe Frontier: The Making of a Colonial Empire, I50o-I80o (Bloomington: Indiana University Press, 2002); Willard Sunderland, Taming the Wild Field: Colonization and Empire on the Russian Steppe (Ithaca, NY: Cornell University Press, 2004).

16. John P. LeDonne, The Grand Strategy of the Russian Empire, I650-I83I (New York: Oxford University Press, 2004), 9-II; Sunderland, Wild Field, 3-5.

17. Wirtschafter, Age of Serfdom, 109-13.

I8. LeDonne, Grand Strategy, 89.

19. Wirtschafter, Age of Serfdom, 129-30.

20. The discussion of Russia's internal political situation uses Old Style dating.

21. Wirtschafter, Age of Serfdom, 130-32, 200-3.

22. Discussion of the wars against revolutionary and Napoleonic France uses New Style dating. The account of the wars provided here relies on: Fuller, Strategy and Power, 177-218; Janet M. Hartley, Alexander I (New York: Longman, 1994); Paul W. Schroeder, The Transformation of European Politics ${ }_{176} 6_{3}-1848$ (New York: Oxford University Press, 1994), 177-582; Lieven, Russia against Napoleon; Oleg Airapetov, Istoriia vneshnei politiki Rossiiskoi imperii. I80I-I9I4. Vol. I: Vneshniaia politika Imperatora Aleksandra I, I802-I825 (Moscow: Kuchkovo pole, 2017).

23. In October 1799, a British-Russian expedition to liberate Holland failed. The French had taken the Ionian Islands in 1797.

24. For recent appraisal of Tilsit from the Russian side, see Claus Scharf, "The Power of the Weak Opponent: The Diplomacy of Alexander I in Tilsit," Journal of Modern Russian History and Historiography I2 (2019): 209-23.

25. Quoted in Scharf, "Weak Opponent," 223.

26. Scharf, "Weak Opponent," 223.

27. Scharf, "Weak Opponent," 222.

28. The partitions of Poland are often depicted as the crowning achievement of Catherine II's foreign policy, yet historians past and present question the efficacy of the empress's success. The late Isabel de Madariaga argued that Catherine's conquests not only endangered Russian security in the west but also required that future actions consider the balance of interests among the three partitioning powers (Austria, Prussia, and Russia). More broadly, Alexander Kamenskii concludes that "none of the initial goals of her [Catherine's] foreign policy that she herself had put forward had in fact been accomplished." Alexander Kamenskii, "Catherine the Great's Foreign Policy Reconsidered," Journal of Modern Russian History and Historiography I2 (2019): 169-87, quote on 186.

29. Fuller, Strategy and Power, I86-90.

30. For detailed treatment, see Lieven, Russia against Napoleon, 138-24I. 
31. Fuller, Strategy and Power, 190. Janet Hartley gives similar numbers: 50,000 Russian and 40,000 French casualties. Hartley, Alexander I, iI5.

32. Lieven, Russia against Napoleon, 257-58.

33. Lieven, Russia against Napoleon, 264-65.

34. Fuller, Strategy and Power, 191-93.

35. Quoted in Lieven, Russia against Napoleon, 240.

36. Imperator Aleksandr I i Frederik-Sezar Lagarp. Pis'ma. Dokumenty, ed. A. Iu. Andreev and D. Tozato-Rigo, trans. V. A. Mil'china, 3 vols. (Moscow: Politicheskaia entsiklopediia, 2014-17).

37. See the appendix.

\section{Chapter I: Pacification and Peace (I815-I7)}

I. The historiographic discussion contained herein is far from exhaustive.

2. The terminology of old regime and new regime is familiar from the historiography of modern France, particularly that of the French Revolution and Napoleonic era. See Isser Woloch, The New Regime: Transformations of the French Civic Order, 1789-1820s (New York: Norton, 1994); Eugen Weber, Peasants into Frenchmen: The Modernization of Rural France, I870-1914 (Stanford, CA: Stanford University Press, 1976). See also Ambrogio A. Caiani, "Re-inventing the Ancien Régime in Post-Napoleonic Europe," European History Quarterly 47, no. 3 (2017): 437-60.

3. David A. Bell, The First Total War: Napoleon's Europe and the Birth of Warfare as We Know It (Boston: Houghton Mifflin Harcourt, 2007); Paul W. Schroeder, The Transformation of European Politics $1763-1848$ (New York: Oxford University Press, 1994); Marie-Pierre Rey, Alexander I: The Tsar Who Defeated Napoleon, trans. Susan Emanuel (DeKalb: Northern Illinois University Press, 20I2).

4. Schroeder, Transformation. See also Mark Mazower, Governing the World: The History of an Idea, I8IS to the Present (New York: Penguin Books, 2012); Jennifer Mitzen, Power in Concert: The Nineteenth-Century Origins of Global Governance (Chicago: University of Chicago Press, 2013). For defense of the balance of power concept, see Wolf D. Gruner, "The Vienna System: Reconstruction of Europe beyond Power Politics, 1812I820: Reflections on New Approaches to the History of International Relations," in The Transformation of European Politics, I763-1848: Episode or Model in Modern History?, ed. Peter Krüger and Paul Schroeder (New York: Palgrave Macmillan, 2002), 165-85.

5. V. M. Bezotosnyi, Rossiia v napoleonovskikh voinakh I805-I8I5 (Moscow: ROSSPEN, 2014), 557-6I; Stella Ghervas, "Balance of Power vs. Perpetual Peace: Paradigms of European Order from Utrecht to Vienna, 1713-1815," The International History Review (2016), https://doi.org/10.1080/07075332.2016.1214613; O. V. Orlik, Rossiia $v$ mezhdunarodnykh otnosheniiakh I8I5-I829: Ot Venskogo kongressa do Adrianopol'skogo mira (Moscow: Nauka, 1998), II-22; Mark Jarrett, The Congress of Vienna and Its Legacy: War and Great Power Diplomacy after Napoleon (New York: I. B. Tauris, 20I 4), chap. 8; Mitzen, Power in Concert, 4-5. 
6. See the collection of articles titled “' 1815 ': The Power of Balance," Journal of Modern European History I3, no. 4 (2015): 427-74, with contributions by Mark Jarrett, Eckart Conze, Beatrice de Graaf, Stella Ghervas, and Matthias Schulz. The phrases quoted here are found on $436-37,465,472$.

7. Adam Zamoyski, Rites of Peace: The Fall of Napoleon and the Congress of Vienna (New York: Harper Perennial, 2007). On the domination of the great powers over small nations, see also Adrian Brisku, "The Holy Alliance as 'An Order of Things Conformable to the Interests of Europe and to the Laws of Religion and Humanity," in Paradoxes of Peace in Nineteenth-Century Europe, ed. Thomas Hippler and Miloš Vec (New York: Oxford University Press, 2015), 153-69. Referring to the Holy Alliance, Brisku writes: "From a Russian imperial historical perspective, Alexander I was reinvigorating a doctrine in foreign policy established by Peter the Great: namely, dominating through the 'protection' of neighbors." More generally, "the Vienna Congress post-war settlement was for a lasting peace deal between the great powers whose interests took precedence over any smaller nation" ( 162 ).

8. On the ability of small states to influence events, see Beatrice de Graaf, "Second-Tier Diplomacy: Hans von Gagern and William I in Their Quest for an Alternative European Order, 1813-1818," Journal of Modern European History I2, no. 4 (2014): 546-66.

9. G. John Ikenberry, After Victory: Institutions, Strategic Restraint, and the Rebuilding of Order after Major Wars (Princeton, NJ: Princeton University Press, 200I), x-xiii, 80I16. On the Vienna system as a "security regime," see Robert Jervis, "A Political Science Perspective on the Balance of Power and the Concert," American Historical Review 97 , no. 3 (June 1992): 716-24. On "security culture" as an emotional concept, see Beatrice de Graaf, "Bringing Sense and Sensibility to the Continent: Vienna i8Is Revisited," in "'I8I5': The Power of Balance," Journal of Modern European History 13, no. 4 (2015): 447-57.

Io. Ikenberry attributes the idea of continuing the alliance to British diplomacy, strategic constraint, and the commitment to allied unity. For him British foreign secretary Castlereagh is the hero of the Vienna settlement, whereas Alexander is the autocratic author of an inconsistent foreign policy. In reality, the achievements and aspirations that Ikenberry attributes to British policy and constitutionalism belonged equally to Russian diplomacy. Ikenberry's statement: "The autocratic and fickle character of the Russian state, as embodied in its leader, doomed the creation of a stronger institutional settlement" (II2), is particularly dismissive and stereotypical. Ikenberry, After Victory, 90-98, 109-16. Henry Kissinger's classic study likewise gives center stage to Castlereagh and Austrian foreign minister Clemens von Metternich. See Henry A. Kissinger, $A$ World Restored: Metternich, Castlereagh and the Problems of Peace, I8I2-I822 (Boston: Houghton Mifflin Company, 1957). See also, Henry Kissinger, "The Congress of Vienna: A Reappraisal," World Politics 8, no. 2 (1956): 264-80. On the coalition politics of 1813-14, see Dominic Lieven, Russia against Napoleon: The True Story of the Campaigns of War and Peace (New York: Penguin Books, 2009).

II. Ikenberry, After Victory, I05-8. Paul Schroeder's views have evolved and moderated over time; however, his remains the strongest voice arguing that the concept of balance of power does not apply to the Vienna settlement. Instead, he argues that the 
settlement established two hegemonic powers or superpowers, Britain and Russia, and three lesser powers-Austria, France, and Prussia-that potentially could exercise hegemonic power in limited regional contexts. See Schroeder, Transformation, 575-82. On the evolution of Schroeder's interpretation, see Gruner, "The Vienna System."

I2. Ikenberry, After Victory, 83. The best English-language account of Russian foreign policy in this era remains Patricia Grimsted, The Foreign Ministers of Alexander I: Political Attitudes and the Conduct of Russian Diplomacy, I80I-I825 (Berkeley: University of California Press, 1969).

13. Niall Ferguson, "The Meaning of Kissinger: A Realist Reconsidered," Foreign Affairs 94, no. 5 (September/October 2015): 134-43.

I 4. The structural approach is advocated in Gruner, "The Vienna System."

I5. Ghervas, "Balance of Power vs. Perpetual Peace”; Bell, Total War, 52-I19; Eliana Augusti, "Peace by Code: Milestones and Crossroads in the Codification of International Law," in Hippler and Vec, Paradoxes of Peace, $4 \mathrm{I}-43$. On the idea of perpetual peace in Russia, see Orlik, Rossiia v mezhdunarodnykh otnosheniiakh, 13-15; A. A. Orlov, "Vospriiatie v Rossii nachala XIX veka idei 'vechnogo mira' (na primere 'Rassuzhdeniia o mire i voine' V. F. Malinovskogo," in Epokha I8I2 goda: Issledovaniia. Istochniki. Istoriografiia, XIII. Sbornik materialov. K 20o-letiiu Venskogo kongressa, ed. V. M Bezotosnyi (Moscow: Kuchkovo pole, 2015), 13: 439-54.

16. These negotiations led to the Third Coalition of 1805 . Grimsted, Foreign Ministers, 104-50. On Emperor Paul, see Hugh Ragsdale, "Russian Foreign Policy, 1763-1815: Does It Exemplify Paul Schroeder's Theses?,” in Krüger and Schroeder, Transformation, I29-5I. Patricia Kennedy Grimsted, "Czartoryski’s System for Russian Foreign Policy, 1803: A Memorandum, Edited with Introduction and Analysis," California Slavic Studies 5 (1970): 19-91.

17. Philipp Menger, Die Heilige Allianz: Religion und Politik bei Alexander I. (I80II825) (Stuttgart: Steiner, 2014), II8-3I; Rey, Alexander I, I5I-56; Schroeder, Transformation, 249-64.

I8. Robert Stewart, Second Marquis of Londonderry, Viscount Castlereagh (1769I822); William Cathcart (1755-1843).

19. C. K. Webster, ed., British Diplomacy I8I3-I8I5: Select Documents Dealing with the Reconstruction of Europe (London: G. Bell and Sons, I92I), I, 389-94.

20. The Novosil'tsev mission led to the British-Russian Convention of II April I805, which called for Russian and Austrian troops, British subsidies and participation in the war with naval and land forces, the return of France to its ancient prerevolutionary frontiers, restoration of the independence of states occupied by France, and territorial compensation for Austria and Prussia. In Schroeder's analysis, the alliance envisioned a blocking coalition against France, a balance of power between the German powers, a barrier system against France for Britain, and protectorates over Germany and Italy for Russia. Schroeder, Transformation, 262-76. Orlov, "Vospriiatie," 452. On the Novosil'tsev mission, see also O. V. Orlik, ed., Istoriia vneshnei politiki Rossii: Pervaia polovina XIX veka (Otvoin Rossii protiv Napoleona do Parizhskogo mira I856 g.) (Moscow: Mezhdunarodnye otnosheniia, 1995), 50. 
21. For recent studies of the Congress of Vienna, see Brian E. Vick, The Congress of Vienna: Power and Politics after Napoleon (Cambridge, MA: Harvard University Press, 20I4); Thierry Lentz, Le congrès de Vienne: Une refondation de l'Europe I8I4-I8IS (Paris: Perrin, 2013).

22. For Castlereagh's project, see Webster, British Diplomacy, 19-33. The treaty was signed on the night of 9-IO March but backdated to I March (NS). For the text of the treaty, see Ministerstvo inostrannykh del SSSR, Vneshniaia politika Rossii XIX $i$ nachala XX veka: Dokumenty Rossiiskogo ministerstva inostrannykh del, first and second series, vols. 6-I2 (Moscow: Gosudarstvennoe izdatel'stvo politicheskoi literatury, Izdatel'stvo "Nauka," 1960-95) (hereafter $V P R$ ). Here $V P R$, v. 7, doc. 233 (17 February/r March I8I4), pp. 587-95. The treaty published in $V P R$ is that between Russia and Austria.

23. In every case where the allies agreed to provide troops, Britain had the option of paying for foreign soldiers instead of providing its own troops. Payments of this sort would be separate from the annual subsidy of 5 million pounds sterling.

24. The Swiss Federation and Spain would be restored to their previous borders. The allies did not carry out the agreed-upon provision to invite the prince of Orange and the monarchies of Portugal, Spain, and Sweden to join the alliance.

25. Exceptions were the Seychelles and Mauritius in the Indian Ocean and Tobago and Santa Lucia in the West Indies. The French part of Santo Domingo went to Spain. The First Treaty of Paris also recognized British control over Malta and the Dutch Cape of Good Hope.

26. Schroeder, Transformation, 507-9; Janet M. Hartley, Alexander I (New York: Longman Publishing, 1994), 128-36.

27. The day after the signing of the First Treaty of Paris, the Swiss cantons accepted a federal pact that brought Geneva into the Swiss Confederation, returned territories taken by France, and recognized Swiss neutrality. In August, following a Norwegian revolt, Norway accepted autonomy under Sweden. Schroeder, Transformation, 513-16.

28. Rey, Alexander I, I84-86; Schroeder, Transformation, 320-23.

29. The liberal Polish constitution was never fully implemented, and the diet remained a consultative body. Orlik, Rossiia v mezhdunarodnykh otnosheniiakh, 24-25.

30. Prince Clemens Wenzel Nepomuk Lothar von Metternich (1773-1859).

31. Preliminary meetings began in September, and Russian scholarship dates the start of the congress to October. Schroeder, Transformation, chap. I2; Ocherki istorii Ministerstva inostrannykh del Rossii. I802-2002 (Moscow: Olma-Press, 2002), v. I, pp. 265-66.

32. Bavaria, Hanover, Hessen-Darmstadt, the United Netherlands, and Sardinia also joined the secret alliance against Prussia and Russia. Some historians see in this alliance France's return to great power status. See $V P R$, v. 8, n. 81, pp. 633-36.

33. Austria kept the district of Tarnopol, controlled Northern Italy, and benefited from the establishment of dependent dynasties in Parma and Tuscany. The compromise on Poland was codified in treaties signed separately by Russia with Austria and Prussia (2I April/3 May I8I5), and in a supplemental treaty on Cracow signed by all three powers (2I April/3 May I8I5). VPR, v. 8, annotations (2I April/3 May I8I5), pp. 294-95. The summary 
of the Polish-Saxon question provided here is based on Schroeder, Transformation, 52338; Rey, Alexander I, 288-89; Kissinger, World Restored, I 49-7I; A. V. Torkunov and M. M. Narinskii, eds., Istoriia mezhdunarodnykh otnoshenii, Tom I: Ot Vestfal'skogo mira do okonchaniia Pervoi mirovoi voiny (Moscow: Aspekt Press, 20I2), I84-85. A treaty of I8I7 delimited the border between Prussia and the Kingdom of Poland; however, uncertainties remained, and negotiations continued until October I820. On 28 April I820 Alexander instructed his representative, General d'Ouvray, to adhere to the stipulations of existing treaties and to continue the "line of moderation" in the negotiations. On 5/17 October 1820 the monarch approved the demarcations proposed by the Polish and Prussian commissars and authorized his envoy in Berlin, Baron David M. Alopeus, to begin negotiations with the Prussian government. At the time, points of disagreement between the two governments remained. AVP RI, f. 133, op. 468, d. 2990, Doklady, 11. 24-25, draft dispatch to Baron Alopeus approved by Alexander (24 February I820); 11. 42-42ob., draft dispatch to General d'Ouvray approved by Alexander (24 February I820); 1. 71, draft office to Count Sobolewski approved by Alexander (3/15 October I820); 11. 72-720b., draft dispatch to Baron Alopeus approved by Alexander (3/15 October 1820); 11. 73-75ob., draft note to Count Bernstorff in Berlin approved by Alexander (3/15 October 1820).

34. Schroeder, Transformation, chap. I2. Recent Russian scholarship counts 2 emperors, 4 kings, 2 princely heirs (naslednykh printsa), 3 grand dukes, 215 heads of princely families, and 450 diplomats and other officials. Ocherki, v. I, pp. 265-66.

35. $V P R$, v. 8, doc. 102 (13/25 March I8I5), pp. 240-45, treaty of alliance between Russia and Britain; annotation ( $13 / 25$ May 1815 ), p. 347, manifesto of Alexander I to the people of the Kingdom of Poland concerning incorporation into the Russian Empire and the granting of a constitution.

36. Schroeder, Transformation, 550-59.

37. Kissinger, World Restored, 171-74; Schroeder, Transformation, 546-73.

38. Kissinger, World Restored, 215-17; Schroeder, Transformation, 560-82.

39. "Tableau statistique de la Confédération Germanique," Le Conservateur impartial, no. 64 (9/21 August I818): 284.

40. A four-power Treaty of 5 November i8Is established the United States of the Ionian Islands to be governed by a British high commissioner in accordance with a constitution written by an Ionian assembly. On British rule in the Ionian Islands, see VPR, v. I (9), doc. 95 (29 October/Io November 1816), pp. 278-84, report from Kapodistrias to Alexander.

41. The Rhine, Neckar, Moselle, Main, Meuse, and Scheldt Rivers.

42. Kissinger, World Restored, 179-84, 215-17; Schroeder, Transformation, 548-60; Rey, Alexander I, 332-33; Hartley, Alexander I, 128-36; Tim Blanning, The Pursuit of Glory: The Five Revolutions That Made Modern Europe: 1648-18I5 (New York: Penguin, 2007), 670-75. A regulation of 19 March I815, further developed in Russian law by the Consular Regulation of 1820 , defined diplomatic ranks across Europe: ambassador (posol), envoy (poslannik), minister plenipotentiary (polnomochnyi ministr), resident minister (ministr-rezident), and chargé d'affaires (poverennyi v delakh). The ambassador personally represented the head of state, the envoy was accredited to the head of the host 
state, and the chargé d'affaires was accredited to the foreign ministry of the host country. Diplomatic ranks also included representatives sent on temporary or extraordinary missions. In 1825 the Russian Empire maintained thirty-four general consulates, nineteen of which were in Europe. Ocherki, v. I, pp. 27I-73.

43. $V P R$, v. 8, doc. 272 (8/20 November 1815), pp. 600-609, peace treaty between Russia and France.

44. In the end the occupation lasted only three years.

45. Rey, Alexander I, 332-33; VPR, v. 8, doc. 273 (8/20 November I815), pp. 609-14, treaty of alliance between Russia and Austria.

46. Matthias Schulz, "Paradoxes of a Great Power Peace: The Case of the Concert of Europe," in Hippler and Vec, Paradoxes of Peace, 13I-52, here 135-36. See also Matthias Schulz, Normen und Praxis: Das Europäische Konzert der Großmächte als Sicherheitsrat, I8IS-I860 (Munich: De Gruyter Oldenbourg, 2009).

47. Jurists of the early nineteenth century regarded codification of international law as premature. Augusti, "Peace by Code," 4I-43.

48. V. M. Bezotosnyi sees the Holy Alliance of the monarchs as the foundation of the Vienna system. In general, Russian scholars assign a more central role to the Holy Alliance than do historians from other European countries. V. M. Bezotosnyi, "Venskii Kongress: Evropa i Rossiia," in Bezotosnyi, Epokha I8I2 goda, I3: 7-I2. Richard Stites describes the Holy Alliance as "the conservative international master document," the product of Alexander I's mystical conversion and Metternich's anti-liberalism. Richard Stites, The Four Horsemen: Riding to Liberty in Post-Napoleonic Europe (New York: Oxford University Press, 2014), Kindle edition, 22.

49. See the article by Ioannis Kapodistrias: "Observations sur les véritables intérêts de l'Europe," Le Conservateur impartial, no. I8 (2/14 March I8I7): 99-IOI. On Kapodistrias's authorship, see $V P R$, v. I (9), annotation (2/14 March 1817), p. 474.

50. Wolfram Siemann, Metternich: Stratege und Visionär. Eine Biografie (Munich: C. H. Beck, 2016); John Bew, Castlereagh: A Life (New York: Oxford University Press, 2012); Rey, Alexander I; Hartley, Alexander I. On the moderate mainstream Enlightenment, see Jonathan Israel, Enlightenment Contested: Philosophy, Modernity, and the Emancipation of Man I670-I752 (New York: Oxford University Press, 2006).

51. The Holy Alliance has its own substantial historiography, which cannot be fully reviewed here. Suffice it to say that inside and outside of Russian Studies, scholarly treatments often portray the alliance either as a tool of monarchical reaction deployed by Austria, Prussia, and Russia or as the product of Alexander I's religious conversion and mysticism. Neither analysis is fully satisfactory, though the monarch's biography and emergent romantic nationalism in Russia do offer productive lines of inquiry. Modern Russian scholarship, including unpublished works from the 1920 and 1930 , is more sophisticated. This scholarship analyzes the Holy Alliance as an expression of mystical religious spirituality, an aspect of European diplomacy, and a system of internal politics. One of the more interesting claims holds that Alexander sought to transform the language of European diplomacy and politics into a language of religious mysticism. V. K. Nadler, Imperator Aleksandr i ideia sviashchennogo soiuza, 5 vols. (Riga: N. Kimmel', 
I886-92); Georgii Florovskii, Puti russkogo bogosloviia (Minsk: Izdatel'stvo Belorusskogo Ekzarkhata, 2006); Francis Ley, Alexandre Ier et sa Sainte-Alliance (I8II-1825) avec des documents inédits (Paris: Librairie Fischbacher, 1975); Andrei Zorin, Kormia dvuglavogo orla. . Literatura i gosudarstvennaia ideologiia v Rossii v poslednei treti XVIIIpervoi treti XIX veka (Moscow: Novoe literaturnoe obozrenie, 200I); Rey, Alexander I; Menger, Heilige Allianz; Brisku, "Holy Alliance." For a clichéd account, see Edward Keene, International Political Thought: A Historical Introduction (Malden, MA: Polity Press, 2005), 172-74. On modern Russian scholarship, see Vadim S. Parsamov, “'Apokolipsis diplomatii' ('Akt o Sviashchennom soiuze’ v interpretatsii K.-V. Metternikha, baronessy Kriudner, Zhozefa de Mestra i Aleksandra Sturdzy)," in Osvoboditel'noe dvizhenie $v$ Rossii, vypusk 20 (Saratov, 2003), 44-66.

52. I began to develop this point in Elise Kimerling Wirtschafter, "Russian Diplomacy as Enlightenment Project: The Holy Alliance and the Vienna Settlement, 1815-1823," in Vek Prosveshcheniia. Vypusk 6: Chto takoe Prosveshchenie? Novye otvety na staryi vopros (Moscow: Nauka, 2018), 208-18.

53. Polnoe sobranie zakonov Rossiiskoi Imperii, series I: I649-1825, 46 vols. (Saint Petersburg: II Otdelenie Sobstvennoi E. I. V. Kantseliarii, 1830) [hereafter PSZ (I)] 33: 25943 (I4/26 September 1815), pp. 279-8I. For the French text, see $V P R$, v. 8, doc. 23I (14/26 September 1815), pp. 516-i8. For the history of the treaty text, see $V P R$, v. $8, \mathrm{n}$. 268, pp. 692-93; n. 276, pp. 695-97.

54. In the French text, "justice, charity, and peace." VPR, v. 8, doc. 23I (I4/26 September I8I5), p. 517.

55. In the French text, "religion, peace, and justice." VPR, v. 8, doc. 23I (I4/26 September 1815$)$, p. 517.

56. From 5 February I8II until George III's death in January I820, the future King George IV reigned as prince regent and de facto sovereign. On the accession of Denmark and German states such as the free city of Bremen to the Holy Alliance, see VPR, v. I (9), doc. 192 (II/23 August 1817), pp. 640-42, rescript from Alexander to P. A. Nikolai; doc. 201 (15/27 September I817), pp. 673-74, Nesselrode to I. O. Anstett.

57. M. M. Speranskii, Rukovodstvo k poznaniiu zakonov, ed. I. D. Osipov (Saint Petersburg: Nauka, 2002), 586.

58. Marc Raeff, Michael Speransky: Statesman of Imperial Russia, 1772-1839 (The Hague: Martinus Nijhoff, 1957), 225-26.

59. Elise Kimerling Wirtschafter, Religion and Enlightenment in Catherinian Russia: The Teachings of Metropolitan Platon (DeKalb: Northern Illinois University Press, 2013).

6o. Quentin Skinner, The Foundations of Modern Political Thought, 2 vols. Vol. I: The Renaissance; Vol. 2: The Age of Reformation (New York: Cambridge University Press, 1978); J. B. Schneewind, The Invention of Autonomy: A History of Moral Philosophy (New York: Cambridge University Press, 1998); G. M. Hamburg, Russia's Path toward Enlightenment: Faith, Politics, and Reason, I500-180I (New Haven, CT: Yale University Press, 2016). On kingship in Russia, see Gail Lenhoff and Ann Kleimola, eds., "The Book of Royal Degrees" and the Genesis of Russian Historical Consciousness (Bloomington, IN: Slavica, 2010); Cynthia Hyla Whittaker, Russian Monarchy: Eighteenth-Century Rulers 
and Writers in Political Dialogue (DeKalb: Northern Illinois University Press, 2003); Richard S. Wortman, Scenarios of Power: Myth and Ceremony in Russian Monarchy from Peter the Great to the Abdication of Nicholas II, one vol. abridged (Princeton, NJ: Princeton University Press, 2006).

6r. Emperor Alexander's wife, Elizabeth Alekseevna, was born Princess Louise of Baden, and his beloved sister Catherine married the Duke of Oldenburg, heir to the duchy. His mother, Maria Fedorovna, was a princess of Württemberg.

62. Alan Sked describes the Holy Alliance as "perhaps the vaguest document ever to trouble European diplomacy." Sked and others repeatedly quote contemporary dismissals of the alliance as a "'loud-sounding nothing" (Metternich) and a "piece of sublime mysticism and nonsense" (Castlereagh). Alan Sked, Introduction to Europe's Balance of Power $1815-1848$, ed. Alan Sked (New York: Harper and Row, 1979), 3-4. Paul Schroeder, by contrast, recognizes that Metternich, Castlereagh, and Alexander all took seriously "the role and value of moral principles in international politics," and he correctly argues that Alexander's idealistic religious language "should not be dismissed as mystical nonsense or a cover for Russian ambitions." Schroeder, Transformation, 558-59. For recent studies that avoid the old stereotypes and highlight the European context, see Anselm Schubert and Wolfram Pyta, eds., Die Heilige Allianz. Entstehung-WirkungRezeption (Stuttgart: W. Kohlhammer, 2018).

63. For Alexander's response to foreign criticism, see his correspondence with Castlereagh, Hardenberg, and Pope Pius VII: VPR, v. I (9), doc. 33 (2I March/2 April I8I6), pp. I08-13, Alexander to Castlereagh; doc. 50 (22 April/4 May i816), pp. I52-56, Alexander to Hardenberg; Grand Duke Nikolai Mikhailovich, L'Empereur Alexandre Ier: Essai d'étude historique, 2 vols. (Saint Petersburg: Manufacture des papiers de l'état, 1912), v. 2 , pp. 210-14. On papal opposition, see also VPR v. I (9), doc. 39 (3I March/ı2 April I8I6), pp. 133-34, dispatch from Nesselrode to Major General F. V. Teil'-fan-Seroskerken (Theodor Tuyll van Seroskerken); doc. 8I (23 August/4 September I8I6), pp. 244-47, Tuyll to Nesselrode; doc. 127 (15/27 January I817), pp. 40I-7, memorandum of instruction to envoy in Rome A. Ia. Italinskii.

For diplomatic correspondence concerning the Ottoman Empire and the Holy Alliance, see $V P R$, v. I (9), doc. 4I (3I March/ı2 April I8I6), pp. 135-37, Nesselrode to envoy in Constantinople A. Ia. Italinskii; doc. 70 (IO/22 July I8I6), pp. 22I-23, supplemental instruction from Nesselrode to envoy in Constantinople G. A. Stroganov. For additional correspondence concerning the Holy Alliance, see also VPR, v. I (9), doc. 44 (7/19 April I816), pp. I40-42, Nesselrode to envoy in Naples G. S. Mochenigo; doc. I25 (Io/22 January 1817), pp. 398-99, Nesselrode to Anstett; doc. 126 (I5/27 January 1817), pp. 400-40I, chargé d'affaires in Switzerland Baron Paul de Krudener to Nesselrode. For the rescript, see $V P R$, v. I (9), doc. 34 (22 March/3 April 1816), pp. I13-17. A related rescript of 18/30 March 1816 explained the principles motivating the Holy Alliance (peace, harmony, and love) and countered claims that it was directed against non-Christian peoples: see Sbornik Imperatorskogo Rossiiskogo istoricheskogo obshchestva (hereafter SIRIO), I 48 vols. (Saint Petersburg: Imperatorskoe Rossiiskoe istoricheskoe obshchestvo, 1867-1916), v. II2, pp. 455-57; N. K. Shil'der, Imperator Aleksandr Pervyi: Ego zhizn'i tsarstvovanie, 4 
vols. (Saint Petersburg: Izdanie A. S. Suvorina, I897-98), v. 3, pp. 532-33; VPR, v. I (9), annotation (I8/30 March I816), p. I00, rescript from Alexander to Lieven; Rossiiskii gosudarstvennyi arkhiv drevnikh aktov (hereafter RGADA), f. I5, op. I, d. 279, Documents concerning relations with European powers from the Ministry of Foreign Affairs, 11. 32-42, circular rescript to ministers at the courts of Vienna, London, Berlin, and Paris (18/30 March 1816); d. 284, On the establishment of the Holy Alliance, ll. I-3ob., rescript from Alexander to Lieven (I8 March I8I6).

64. PSZ (I) 33: 26045 (Manifesto of 25 December 1825), p. 417; Sobranie Vysochaishikh manifestov, gramot, ukazov, reskriptov, prikazov voiskam i raznykh izveshchenii posledovavshikh v techenii I8I2, I813, I8I4, I8I5 i I8I6 godov (Saint Petersburg: Morskaia tipografiia, 1816), 187-92.

65. The Festal Menaion, trans. Mother Mary and Archimandrite Kallistos Ware (South Canaan, PA: Saint Tikhon's Seminary Press, 1998), so.

66. Festal Menaion, 51.

67. Festal Menaion, 4I-42, 50-5I. On the liturgical symbolism surrounding the Holy Alliance, see also Andrei Iu. Andreev, “Nachalo 'novogo veka': Rozhdestvenskaia simvolika v tsarstvovanii Aleksandra I," Vestnik PSTGU. II. Istoriia. Istoriia Russkoi Pravslavnoi Tserkvi, vypusk I (44) (20I2): 40-48; Andrei Iu. Andreev, "'Liturgika' Sviashchennogo soiuza: K voprosu o religioznykh vzgliadakh Aleksandra I,” Filaretovskii al'manakh, ed. A. I. Iakovlev, vypusk I2 (Moscow: Izdatel'stvo PSTGU, 2016), I23-54.

68. Territorial disputes and political conflicts did not cease with the signing of the Vienna and Paris treaties. In Germany, Italy, Poland, and Scandinavia, details of internal governance and the broader European settlement still had to be negotiated and codified. As brief perusal of the Polnoe sobranie zakonov reveals, there is no full account of the numerous treaties, conventions, and accords signed by Russia with other states during these years. The archival record highlights additional subjects in need of comprehensive research: delimitation of the Prussian-Polish border; economic relations and accords between Prussia and the Kingdom of Poland; and Russia's trade agreements and tariff policies. See the draft dispatches approved by Alexander and cited above. See also AVP RI, f. I33, op. 468, d. 2991, Doklady, ll. I-3ob., draft dispatch to Count Gur'ev (Gourieff) approved by Alexander (15/27 January I82I); 11. 590b.-63, draft verbal note to British ambassador Sir Charles Bagot approved by Alexander (2 July I82I); 11. 68-68ob., draft dispatch to Baron Nikolai in London approved by Alexander (2 July I82I); 11. 75-80ob., draft note to the minister of Sweden Baron (Nil's-Frederik) Palmstierna approved by Alexander (I3 August I82I); 11. I20-3I, draft dispatch to Count Alopeus approved by Alexander (13 October I82I); d. 2992, Doklady, 11. 83-87, report presented to Alexander on freedom of trade for the city of Podgorze (3 February 1820 ).

69. RGADA, f. I5, op. I, d. 279, 11. 8-310b., general instruction sent to all missions of H. I. M. from Vienna (15/17 May I815).

70. Ready or not, the potential aggression has to be evaluated with reference to the secret alliance of 3 January I8 15 concluded by Austria, Bavaria, Britain, France, Hanover, Hessen-Darmstadt, the United Netherlands, and Sardinia, and directed against Prussia and Russia. 
71. In the end the Ottoman Empire remained outside the European system.

72. C. A. Bayley, "The Age of Revolution in Global Context: An Afterword," in The Age of Revolutions in Global Context, c. $1760-1840$, ed. David Armitage and Sanjay Subrahmanyam (Basingstoke: Palgrave Macmillan, 2010), Kindle edition, location 4851-4943.

73. From the post-colonial perspective, the notion of a moral superiority that justifies expansionist policies is overtly imperialistic, if not also racist.

74. Count Karl von Nesselrode [Karl Vasil'evich Nesselrode (1780-1862)]; Count Ioannis Kapodistrias [John Capo d'Istria; Ivan Antonovich Kapodistrias (1776-183I)]; Count Christoph von Lieven [Khristofor Andreevich Liven (1774-1839)]; Count Gustav Stackelberg [Gustav Ottonovich Shtakel'berg (1787-1850)]; Grand Prince Constantine Pavlovich (1779-1831). Constantine Pavlovich served as governor-general (namestnik) of the Polish Kingdom and commander-in-chief of the Polish army from I8I5 to I83I.

75. VPR, v. I (9), doc. 17 (25 January/6 February 1816), pp. 63-68, Lieven to Nesselrode. 76. Arthur Wellesley, first Duke of Wellington (1769-1852).

77. $V P R$, v. I (9), doc. 30 (8/20 March I816), pp. 96-100, Nesselrode to Stackelberg. See also $V P R$, v. I (9), doc. 22 (7/19 February i816), pp. 80-8I, Alexander to Victor Emmanuel I (of Sardinia); doc. 23 (13/25 February 1816), pp. 82-85, Nesselrode to envoy in Turin P. B. Kozlovskii.

78. VPR, v. I (9), n. 20, p. 682; RGADA, f. I5, op. I, d. 279, 11. 67-68ob., appendix to the overview of $5 / 17$ June 1817 on Austria's intention to incorporate Novaria and enter into a separate alliance with Sardinia.

79. $V P R$, v. I (9), doc. 136 (31 January/ı2 February I817), pp. 450-53, personal letter from Kapodistrias to Stackelberg.

80 . Here Alexander distinguished between allied governments and his fellow sovereigns who had imbibed the Gospel's pure morality.

81. Napoleon annexed Austria’s Illyrian provinces in 1809 . Lieven, Russia against Napoleon, $\mathrm{I} 7 \mathrm{I}$.

82. VPR, v. I (9), doc. I 46 (9/2 I March I817), pp. 487-90, personal letter of Stackelberg to Kapodistrias; n. 220, pp. 740-4I. See also the reports of the French ambassador in Russia, the count of La Ferronnays, in SIRIO, v. I27.

83. $V P R$, v. I (9), doc. 166 (I/13 May 1817), pp. 537-42, Lieven to Nesselrode.

84. $V P R$, v. I (9), doc. I84 (Io/22 June I8I7), pp. 59I-95, Nesselrode to Lieven.

85. VPR, v. I (9), doc. I5I (2I March/2 April I817), pp. 502-6, Kapodistrias to Grand Prince Constantine Pavlovich.

86. $V P R$, v. I (9), annotation (17/29 March 1817), p. 502, memorandum of the Ministry of Foreign Affairs serving as an instruction to envoys in Vienna, Madrid, Brussels, and Stockholm; to minister plenipotentiary in Paris; and to ambassador in London; $\mathrm{n}$. 230, p. 743.

87. SIRIO, v. I19, pp. 239-48; VPR, v. I (9), annotation (2/14 June I817), p. 578. For the Russian version, dated 5/17 June I8I7, with accompanying documents, see RGADA, f. I5, op. I, d. 279, 11. 43-103ob.

88. In 1808 the Portuguese royal family relocated to Rio de Janeiro, and in 1822 Brazil declared independence. 
89. Based on the Final Act of the Congress of Vienna, the duchies of Parma, Plaisance, and Guastalla belonged to Marie Louise, archduchess of Austria and wife of Napoleon, and her descendants. Britain and France supported the Spanish claim that following the death of Archduchess Marie Louise, these territories should go to the infante Marie Louise, daughter of the former Spanish king, Charles IV; her son Charles Louis; and his direct male descendants. The allies finalized this line of succession in the General Act of the Frankfurt Territorial Commission (8/20 July I8I9), except for districts on the left bank of the Po recognized as Austrian territory. In addition, the treaties assigned the Principality of Lucca to the Grand Duchy of Tuscany upon the death of the archduchess. RGADA, f. I5, op. I, d. 279, 11. 69-730b., appendix to the overview of $5 / 17$ June 1817 on matters concerning the Baden court.

90. Alexander Ivanovich Chernyshev (1785-1857) served as minister of war from 1832 to I852. VPR, v. I (9), annotation (21 April/3 May I817), p. 526, Nesselrode to Alopeus.

91. Brendan Simms, Europe: The Struggle for Supremacy, from 1453 to the Present (New York: Basic Books, 2013), I68, I8I-88; Schroeder, Transformation, 487-88, 572$78,766-77$.

92. Allied involvement resumed in 1818 during negotiations over Swedish responsibility for Norway's debts. The allies agreed that Sweden should honor Norwegian debts based on article 6 of the Treaty of Kiel.

\section{Chapter 2: Completion of the General Alliance (1817-20)}

I. Documents of the era are filled with references to France's natural position as a great power in Europe. See, for example, $V P R$, v. I (9), annotation (9/2I June I8I7), p. 591, Kapodistrias to Richelieu; SIRIO, v. I19, no. II9 (9/21 June I817), pp. 255-57, Kapodistrias to Richelieu. Prior to, during, and after the Congress of Aix-la-Chapelle, the regularization of France's status seemed an urgent matter and also the best means to promote the country's political stability, which remained a serious concern for the allies. $V P R$, v. 2 (I0), doc. II3 (6/18 May I8I8), pp. 367-70, Lieven to Kapodistrias; doc. I49 (not before I6/28 September I818), p. 503, memorandum of Alexander to Russia's plenipotentiaries at the Congress of Aix-la-Chapelle; doc. 165 (3/15 November 1818), pp. 570-74, general circular instruction from the Ministry of Foreign Affairs to Russia's diplomatic missions; annotation (9/21 November 1818), p. 584, circular rescript from Alexander to Russia's diplomatic representatives abroad; annotation (13/25 December I8I8), p. 6II, Kapodistrias to Pozzo di Borgo; doc. I80 (I9/3 I December I8I8), pp. 6II-25, memorandum of Kapodistrias; annotation (25 January/6 February I819), p. 646, Alexander to Richelieu; doc. I87 (25 January/6 February i819), pp. 647-49, circular dispatch from Nesselrode to Russia's diplomatic representatives abroad; doc. 198 (16/28 February 1819), pp. 691-98, Golovkin to Nesselrode; doc. 199 (I7 February/I March I8I9), pp. 698-70I, Golovkin to Nesselrode; annotation (25 February/9 March I8I9), p. 70I, Pozzo di Borgo to Nesselrode; doc. 205 (3I March/12 April I819), pp. 712-17, Nesselrode to Lieven and Alopeus; VPR, v. 3 (II), doc. 56 (22 November/4 December I819), pp. 166-72, memorial memorandum from the Russian 
cabinet to the governments of Austria, Britain, and Prussia; RGADA, f. I5, op. I, d. 279, Documents concerning diplomatic relations with European powers from the Ministry of Foreign Affairs, 11. I04-270b., on the calculation and payment of France's debts to the subjects of other powers, approved by the emperor (23 October 1817); d. 284, On the establishment of the Holy Alliance, 11. 13-26, general and circular instruction to all missions sent from Aix-la-Chapelle (3/15 November 1818); d. 279, 11. 128-43, Russian version.

2. For detailed treatment, see Heinz Duchhardt, Der Aachener Kongress I818: Ein europäisches Gipfeltreffen im Vormärz (Munich: Piper Verlag, 2018).

3. The "system of conferences" refers to ambassadorial conferences such as those established in Frankfurt, London, and Paris to deal with the implementation of the Paris peace treaties, territorial arrangements in Germany, and the abolition of the slave trade. In the years following the Vienna Congress, ambassadorial conferences functioned as semi-permanent bodies tasked with monitoring or negotiating specific relationships and policies. Ambassadorial conferences remained distinct from the meetings of the great powers (Austria, Britain, France, Prussia, and Russia) that brought together heads of state and/or their representatives to discuss unresolved questions and respond to new crises that arose. Henry Kissinger, A World Restored: Metternich, Castlereagh and the Problems of Peace, I8I2-I822 (Boston: Houghton Mifflin Company, 1957), 221-29. On the idea of a united Europe, see $V P R$, v. 2 (Io), doc. 449 (not before 16/28 September I818), p. 503, memorandum from Alexander to Russia's plenipotentiaries at the Congress of Aix-la-Chapelle. Throughout I8I7 Kapodistrias had pushed for a treaty of guarantee. $V P R$, v. 2 (IO), n. 215, pp. $770-72$.

4. O. V. Orlik, ed. Rossiia v mezhdunarodnykh otnosheniiakh I8I5-I829: Ot Venskogo kongressa do Adrianopol'skogo mira (Moscow: Nauka, 1998), 29-35; Marie-Pierre Rey, Alexander I: The Tsar Who Defeated Napoleon, trans. Susan Emanuel (DeKalb: Northern Illinois University Press, 2012), 335-37; Paul W. Schroeder, The Transformation of European Politics $1763-1848$ (New York: Oxford University Press, 1994), chap. 3; Kissinger, World Restored, 225-29.

5. VPR, v. 2 (IO), doc. 127 (24 June/6 July I818), pp. 409-33, report from the Ministry of Foreign Affairs to Alexander.

6. According to the report, failed efforts by Austria and Britain to renew the Treaty of Chaumont had led to the Quadruple Alliance of 8/20 November I8I5. Historians tend to describe the Quadruple Alliance as the reaffirmation of Chaumont.

7. The "affaire de Parme" resulted from article 99 of the Final Act of the Congress of Vienna, which both assigned the Italian territories of Parma, Plaisance, and Guastalla to Empress Marie Louise, wife of Napoleon, and also allowed for their reversion to Spain. Based on article 99, the Bourbon Spanish king opposed giving the Italian duchies to Archduchess Marie Louise of Austria and her descendants. Russia sought Spanish accession to the Final Act of the Congress of Vienna, and Britain and France supported Spain's claims to the duchies upon the death of Marie Louise. Based on the Treaty of 29 May/10 June I817, signed by Austria, Britain, France, Prussia, Russia, and Spain, and then finalized in the Final Act of the Territorial Commission of Frankfurt, signed by Austria, Britain, Prussia, and Russia, at the death of Archduchess Marie 
Louise of Austria, the duchies would pass to the infante Marie Louise of Spain, her son Charles Louis, and his direct male descendants. Districts on the left bank of the Po would remain under Austrian control, and the Principality of Lucca would pass to the Grand Duchy of Tuscany. Austria also would maintain a garrison in Plaisance. F. F. Martens, ed., Recueil des traités et conventions, conclus par la Russie avec les puissances étrangères, Is vols. (Saint Petersburg: Tipografiia Ministerstva Putei Soobshcheniia, 1874-1909), v. 3, no. 79-96, Final Act of the Congress of Vienna with appendices (28 May/9 June I8I5), pp. 207-315; v. 4, no. 107 (29 May/ıo June I817), pp. 55-61; no. IIo (8/20 July I8I9), pp. I46-86; no. III (4/16 March I8I6), pp. I87-204; no. II2-I3 (I9/30 June I8I6), pp. 204-24; no. II 4 (27 October/8 November I8I6), pp. 224-38; no. II5 (4/16 November I816), pp. 238-40; no. II6 (28 February/i2 March 1817), pp. 24I-42; no. II7 (5/17 April I8I7, 2I November I8I5), pp. 243-46; no. II8 (29 May/ıo June I8I7), p. 246; no. II9-20 (29 June/IO July I8I9), pp. 246-5I; no. I2I (2/I4 April I8I6), pp. $25 \mathrm{I}-64$.

8. Kapodistrias argued that Spanish interests in the Americas, which fell outside the separate and exclusive system of the Quadruple Alliance, should be negotiated legally and publicly.

9. The question of ending the military occupation already had been negotiated with France by the Duke of Wellington, acting on behalf of the allies.

Io. In earlier communications Kapodistrias and other diplomats developed similar arguments critical of the Quadruple Alliance and of Austrian and British policy. See the response of General Karl O. Pozzo di Borgo, Alexander's representative in Paris, to instructions sent by Kapodistrias in a dispatch of 27 March/8 April I8I8: SIRIO, v. II9, no. 306 (25 April/7 May I818), pp. 674-88; VPR, v. 2 (Iо), annotation (25 April/7 May I8ı), p. 35I. A few months later, Kapodistrias, speaking on behalf of Alexander, reminded Pozzo di Borgo that the emperor did not seek to establish a special relationship with France or Spain, that he continued to see allied unity and adherence to existing treaties as necessary for peace, and that Pozzo di Borgo should moderate his public pronouncements of affection for France. See Kapodistrias's letter of Io/22 July I818, published in SIRIO, v. II9, no. 347, pp. 772-77. On British concerns about Pozzo di Borgo's partiality toward France, see $V P R$, v. 2 (Iо), doc. 134 (10/22 July I818), pp. 457-62, secret and confidential letter from Kapodistrias to Lieven.

II. Kapodsitrias's suspicions about Austrian and British efforts to undermine Russia, this time through alliances with the Persian and Ottoman empires, persisted after the Congress of Aix-la-Chapelle. See VPR, v. 2 (Iо), doc. 180 (19/3I December I8I8), pp. 6II25 , memorandum of Kapodistrias. In I816 Russia had encouraged Italian states to resist Austrian encroachments and even suggested the possibility of allied intervention (which did not in this context mean military action). Formal intervention by the alliance could be moral or political instead of military. See $V P R$, v. I (9), doc. 22 (7/19 February 1816), pp. 80-8I, Alexander to Victor Emmanuel I; doc. 23 (I3/25 February I8I6), pp. 82-85, Nesselrode to envoy in Turin P. B. Kozlovskii; doc. 40 (3I March/ı2 April I816), pp. 134-35, Nesselrode to Major General F. V. Teil'-fan-Seroskerken (Theodor Tuyll van Seroskerken); v. 2 (Iо), doc. 144 (I6/28 April I818); pp. 489-93, Nesselrode to A. V. Sverchkov. 
I2. Johann Peter Friedrich Ancillon (1767-1837), author of M. F. Ancillon, Tableau des revolutions du système politique de l'Europe depuis la fin du quinzième siècle, 7 vols. (Paris: Imprimerie de la Harpe, I806-1807). Many diplomatic documents of the era did not use the label Holy Alliance but rather Treaty of Alliance of I $4 / 26$ September I8I5.

13. Territorial disputes would be decided by arbitration at congresses attended by rulers or their representatives.

I4. On 2/14 October 1818, Russia's plenipotentiaries to the congress in Aix-la-Chapelle submitted a memorandum to the ministers of Austria, Britain, and Prussia, as well as to Friedrich von Gentz and the Duke of Wellington, in which they analyzed the Treaty of Chaumont in relation to the Quadruple Alliance. In diplomatic negotiations, the memorandum argued, the principle of analysis assumes that a treaty establishes an obligation and that every obligation carries a cause or motivation (motif) and a goal (but). The legal act of the treaty sets the means to establish the one and expect the other. The motivation of the four signatories to Chaumont was peace with Bonaparte, the goal was an armed defensive system directed against him, and the means were a "pact of solidarity" that guaranteed the mutual security of the four powers and offered the same to other European states seeking to escape domination by the conqueror. Subjecting the Quadruple Alliance to the same principles of analysis, the memorandum identified its motivation as preservation of the general peace founded on the restoration of the French monarchy and the Final Act of the Congress of Vienna. The goal of the alliance was a system armed against France in the sole instance that France violated the pact uniting it, as a legitimate and constitutional kingdom, to the "European family." Finally, the means were the solidarity of the contracting parties on the following points: exclusion of the Bonaparte family from the throne of France, concert with the king of France to resist revolution and combat revolutionary attacks on legitimate and constitutional monarchy, military measures to assist the army of occupation if it was attacked, an armed federation in the event that a France in revolution became a threat to the stability of the European system, and meetings of the sovereigns to ensure execution of the treaties and consolidate the relations that united them for the happiness of the world. $V P R$, v. 2 (Io), doc. I54 (2/I4 October I8I8), pp. 5I4-I7, memorandum from Russia's plenipotentiaries at the Congress of Aix-la-Chapelle to the plenipotentiaries of Austria, Britain, and Prussia.

15. One should add here, the commitment to preserve the ascendancy of the great powers, though only rarely and inadvertently did diplomatic documents of the time admit to this goal.

16. An electrifying and romantic historical figure, Kapodistrias went on to become the first provisional president of modern Greece.

17. For an earlier account of Russia's proposal for a treaty of guarantee, see Elise Kimerling Wirtschafter, "The Congress of Aix-la-Chapelle (1818) and Russia's Proposal for a Treaty of Guarantee," Journal of Modern Russian History and Historiography 12 (2019): 245-62. Henry Kissinger describes Alexander's proposal for a treaty of guarantee as "a doctrine of general interference in the domestic concerns of all states superimposed on a system of collective security." Kissinger, World Restored, 225-26.

I8. SIRIO, v. II9, no. 370 (26 September/8 October I8I8), pp. 832-44. 
19. When revolution returned to France in 1830 , the allies did not act to defend legitimate sovereignty or protect Europe from the revolutionary spirit.

20. RGADA, f. 3, op. I, d. I62. This file (delo), titled Précis du Travail des Conférences d'Aix-la-Chapelle, comes from the archives of Kapodistrias and does not represent a full record of the congress proceedings. Although it contains copies of the official protocols, it does not include the supplements (annexes) attached to individual sessions.

21. For a pioneering study of the occupation of guarantee as it developed on the ground, see Christine Haynes, Our Friends the Enemies: The Occupation of France after Napoleon (Cambridge, MA: Harvard University Press, 2018).

22. The conference protocols used New Style dating, whereas Russian sources generally used double dating, Old Style and New Style.

23. A note from Richelieu dated io September I8I7 urged the allies to ease the financial burden placed on France by modifying the terms of compensation for private claimants as prescribed in the Treaty of 30 May I8I 4 and Convention of $8 / 20$ November 1815. Emperor Alexander immediately supported this request, arguing that the Treaty of $8 / 20$ November I8I5 aimed to ensure the political existence of France in the interest of European peace. In general, the allies rejected changes to the treaties of I8I4-I5; however, in this case, citing the seventeenth-century Dutch jurist, Hugo Grotius, diplomats could argue that events on the ground (France's inability to pay an unexpectedly enormous sum) altered the presumed basis for the convention. Thus, the terms of the convention could be changed without violating the principle of legality. At the same time, Alexander tried to make clear that his support for the French position in no way indicated a special interest in France or the pursuit of a partial advantage in Russia's dealings with France or Spain. SIRIO, v. II9, no. 2 II (27 October/8 November 18I7), pp. 438-43; no. 213 (30 October/II November 1817), pp. 445-46; no. 214-15 (I/13 November 1817), pp. 446-60. Documents elaborating Russia's views on the allied occupation, French exiles, and the French debt can also be found in RGADA, f. I5, op. I, d. 279, 11. 91-96, 104-270b., appendices to the overview of 5/17 June 1817. Finally, in April I820, Alexander agreed to pay more than 179,000 francs to compensate France for the cost of Russian troops that had not left the kingdom when the army of occupation departed. AVP RI, f. 133, op. 468, d. 2990, Doklady, 11. 27-27ob., draft dispatch to General Pozzo di Borgo approved by Alexander (I3 March I820); d. 2991, Doklady, 1l. 49-500b., draft dispatch to Mr. Schröder approved by Alexander (24 April/6 May I82I).

24. $V P R$, v. 2 (I0), annotation (27 September/9 October I8I8), p. 514 , convention between Russia and France; Martens, Recueil, v. 7, no. 288, (27 September/9 October 1818), pp. 302-6; RGADA, f. 3, op. I, d. 162, 1l. 4ob.-6ob., sessions of 9, II, I2, I3 October; 11. I4-I5ob., sessions of 3, 4 November.

25. In response to subsequent requests from France, the allies agreed at the sessions of II and 19 November to extend the period for payment of the French debt to June 1820 . RGADA, f. 3, op. I, d. 162, 1l. 32-33ob., session of II November; 11. 65ob.-68, session of I9 November. On the claims of French subjects against foreign governments, see RGADA, f. 3, op. I, d. 162, ll. Ioob.-II, session of 22 October; 1l. 620b.-64ob., sessions of 16, I8 November. On private claims against the French government, see Martens, Recueil, v. 
I4, no. 516 (13/25 April I8I8), pp. 38I-94; $V P R$, v. 2 (I0), annotation (13/25 April I8I8), p. 317, convention between Russia, Austria, Britain, Prussia, and France on the debts of the French government. On liquidation of the French debt and military contributions, see Martens, Recueil, v. I4, no. 517 (20 January/2 February 1819), pp. 395-442; v. 7, no. 288-96 (27 September/9 October 1818, 23 October/4 November 1818, 31 October/12 November I8I8, 3/15 November I8I8, 4/16 November I8I8, 9/2 I November I8I8), pp. 29I328. For more detailed historical analysis, see Eugene N. White, "Making the French Pay: The Costs and Consequences of the Napoleonic Reparations," European Review of Economic History 5, no. 3 (200I): 337-65; Glenda Sluga, "Who Hold the Balance of the World?' Bankers at the Congress of Vienna, and in International History," American Historical Review 122, no. 5 (December 2017): 1403-30; Marion Koschier, "Der Aachener Mächtekongress von 1818 und die Frage der französischen Reparationszahlungen," in Mächtepolitik und Friedenssicherung. Zurpolitischen Kultur Europas im Zeichen des Wiener Kongresses, ed. Reinhard Stauber, Florian Kerschbaumer, and Marion Koschier (Berlin: LIT Verlag, 2014), I35-51.

26. RGADA, f. 3, op. I, d. 162, 11. 9-10ob., session of 19 October.

27. Martens, Recueil, v. 7, no. 289 (23 October/4 November I818), pp. 306-9; no. 290 (3I October/12 November I8I8), pp. 309-II.

28. On the exchange of notes with Richelieu and the protocol signed by the five powers, see RGADA, f. 3, op. I, d. 162, 11. 59ob.-62, session of I5 November; 11. 82-82ob., note from the plenipotentiaries of the four courts (23 October/4 November 1818); 11. 83-830b., response of Richelieu to the proposal of the allies (3I October/I2 November I8I8); 11. 84-84ob., protocol of $3 /$ is November 1818 .

29. Martens, Recueil, v. 7, no. 292 (3/15 November 1818), pp. 314-18; no. 293 (3/15 November I818), pp. 318-2I; RGADA, f. 3, op. I, d. I62, 11. 540b.-59, sessions of I4, I5 November; 11. 730b.-74, session of 21 November.

30. RGADA, f. 3, op. I, d. 162, 11. 730b.-74, session of 21 November.

31. Martens, Recueil, v. 7, no. 294 (3/15 November 1818), pp. 321-23; RGADA, f. 3, op. I, d. I62, 11. 590b.-62, session of is November; 11. 85-85ob., declaration of I5 November.

32. These developments are covered in a communication of 6/18 May 1818 from Russia's ambassador in London, Christoph Lieven, to Kapodistrias. The Hanoverian memorandum expressed distrust of Austria and mentioned Bavaria and the Netherlands as second-order powers eager to arouse opposition to the tribunal of the great powers. As noted, the allies did invite the Netherlands to sign the Military Protocol, which did not include France. $V P R$, v. 2 (Iо), doc. II2 (6/18 May I8I8), pp. 364-67, Lieven to Kapodistrias. The treaties of Westphalia had established a state system based on the principles of sovereignty, territorial integrity, non-intervention, and "greatpower restraint and accommodation." Formally equal and independent, states constituted "rightful political units for the establishment of legitimate rule." G. John Ikenberry, "The Logic of Order: Westphalia, Liberalism, and the Evolution of International Order in the Modern Era," in Power, Order, and Change in World Politics, ed. G. John Ikenberry (Cambridge: Cambridge University Press, 2014), Kindle edition, location 2264-2322. 
33. RGADA, f. 3, op. I, d. 162, 11. 79-81ob., session of 22 November, special conference; $V P R$, v. 2 (IO), doc. 174 (II/23 November I818), pp. 589-91, memorial memorandum from Russia's plenipotentiaries to the plenipotentiaries of Austria, Britain, Prussia, and France. Russian officials did not expect this initiative to produce results. As early as 3/15 November, Alexander approved a general circular instruction addressed to all of the empire's diplomatic missions. The instructions expressed satisfaction with the agreements concluded in Aix-la-Chapelle, emphasized the importance of allied unity in preserving the peace, and ordered strict adherence to all existing treaties, which were beneficial for all European states. VPR, v. 2 (I0), doc. 165 (3/15 November 1818); pp. 570-74, general circular instruction from the Ministry of Foreign Affairs to Russia's diplomatic missions; SIRIO, v. I19, no. 371, pp. 844-50; RGADA, f. I5, op. I, d. 284, 11. 13-26, general and circular instruction to all missions sent from Aix-la-Chapelle (3/15 November 1818), d. 279 , 11. I28-43, Russian version. The instructions were affirmed in early 1819: $V P R$, v. 2 (I0), doc. I87 (25 January/6 February I819), pp. 647-49, circular dispatch from Nesselrode to Russia's diplomatic representatives abroad.

34. The quoted phrase repeated wording found in the Second Treaty of Paris. VPR, v. 8, doc. 272 (8/20 November I8I5), pp. 600-9.

35. The Russian government already understood that Britain would not agree to the collective guarantee, but still hoped that the other allies could be persuaded. Kissinger, World Restored, 226-29; Schroeder, Transformation, chap. I3.

36. Martens, Recueil, v. 4, no. IIO-21, pp. I46-264. For the text of the General Act, see no. iıo (8/20 July I8I9), pp. I46-86.

37. Reports from 1820-21 preserved in the archive of the Ministry of Foreign Affairs identify some of the long-term negotiations and disputes. Specific cases include delimitation of the Polish-Prussian border; trade relations between Prussia and the Kingdom of Poland; Russia's trade relations with Sweden (and Norway); Swiss claims against Baden; navigation of the Weser River; freedom of commerce for the city of Podgorze, which Austria's line of tariffs separated from Galicia and therefore put at a disadvantage in relation to merchants from the free city of Cracow; individual claims for financial compensation and land, including the claims of François Borghèse, Prince Aldobrandini, against Hessen-Darmstadt, Bavaria, and Prussia for the saltworks of Kreutznach and Durckeim. AVP RI, f. I33, op. 468, d. 2990, Doklady, 1l. 24-24ob., 37-370b., 7I, 42-42ob.; d. 229I, Doklady, 1l. 75-80ob., I20-3I; d. 2992, Doklady, 1l. I5-26ob., 42440b., 57-59ob., 83-87, 252-550b.; VPR, v. 2 (10), annotation (7/19 December 1818), p. 596, trade convention between Russia and Prussia; v. 3 (II), doc. 92 (II/23 February I820), pp. 264-65, note from Nesselrode to Austria's envoy in Saint Petersburg, Ludwig Joseph Lebzeltern (1774-1854); AVP RI, f. I87, op. 524, d. 37, Various memorandums, projects, plans from $1820-28,11$. $52-630 b$., memorandum to the great allied powers from Prince Aldobrandini. In October 1820 , the Russian government worked steadily to complete the negotiations between Prussia and the Kingdom of Poland. At this stage in the peacemaking process, decisions about the delimitation of borders mostly impacted tariff revenues and other economic interests. AVP RI, f. I33, op. 468, d. 2990, Doklady, 11. 72-720b., draft dispatch to Baron Alopeus approved by Alexander (3/15 October 1820); 
73-75ob., draft note to [Prussian minister of foreign affairs] Count [Christian Gunther] Bernstorff [1769-I835] in Berlin approved by Alexander (3/15 October 1820).

38. For analysis that places Central Europe at the center of the peace settlement, see Brendan Simms, Europe: The Struggle for Supremacy, from 1453 to the Present (New York: Basic Books, 2013).

39. See RGADA, f. I5, op. I, d. 533, Alexander's instructions of $3 / 15$ February i815 to Russia's first plenipotentiary at the Congress of Vienna, Count Andrei K. Razumovskii. 40. RGADA, f. 3, op. I, d. 162, 11. 5-5ob., session of II October; 11. 6ob.-7, sessions of I2, I3, I 4 October.

4I. According to Kapodistrias, the fragile health of the grand duke also required that a decision be reached. VPR, v. 2 (I0), doc. 150 (17/29 September I818), pp. 504-9, report from Kapodistrias to Alexander.

42. RGADA, f. 3, op. I, d. I62, 11. 5ob.-6, session of I2 October; 11. 7-8ob., sessions of 13, I 4, 17 (?) October; 11. 13-14, sessions of 29 October, 3 November; 11. 27-31, sessions of 9, ro November; 1l. 46ob.-48, session of 14 November; 1l. 69ob. -72 , sessions of 20 , 2I November.

43. RGADA, f. I5, op. I, d. 279, 11. 69-73ob., affairs of the Baden court; VPR, v. 8, doc. 172 (I7/29 June I8I5), pp. 387-91, secret instruction from Alexander to Pahlen; $n$. 203-4, p. 68I.

44. The treaties mentioned were the Treaty of Frankfurt of $8 / 20$ November 1813 and the Treaty of I5 May i815.

45. Martens, Recueil, v. 4, no. I10 (8/20 July I8I9), pp. I46-86; no. I19-20 (29 June/ı July I8I9), pp. 246-5I; no. I2I (2/I4 April I8I6), pp. 25I-64; VPR, v. 2 (IO), doc. 200 (5/17 March I8I9), pp. 702-3, Nesselrode to Pahlen; n. 309, pp. 84I-42; v. 3 (II) doc. 73 (23 December I819/4 January I820), pp. 205-10, memorandum of instruction from the Ministry of Foreign Affairs to Russia’s diplomatic representatives abroad.

46. RGADA, f. 3, op. I, d. I62, 11. 21-310b., sessions of 7, 9, Io November. For basic information about the boundaries and status of German states, I rely on Gerhard Köbler, Historisches Lexikon der deutschen Länder: Die deutschen Territorien und reichsunmittelbaren Geschlechter vom Mittelalter bis zur Gegenwart (Darmstadt: Wissenschaftliche Buchgesellschaft; Munich: C. H. Beck, 1988). Except for place names that have recognized Anglophone equivalents, I follow the spelling found in Köbler. For allied pledges to assist German states in obtaining land swaps, see also Martens, Recueil, v. 3, no. 79-96 (28 May/9 June I8I5), pp. 207-315, especially pp. 272-73 for articles 49-50.

47. $V P R$, v. 2 (I0), doc. 150 (17/29 September 1818 ), pp. 504-9, report from Kapodistrias to Alexander; doc. ${ }_{169}$ (9/21 November 1818), pp. 58I-82, letter from Alexander to William I of Hessen-Kassel (identical letters were sent Frederick William III and Castlereagh). In spring 1820 individual claims for the restitution of property continued to reach Russia's Ministry of Foreign Affairs. For a claim involving private property that was transferred from French to Russian forces and then from the commander of Russian troops to the city of Hamburg, see AVP RI, f. I33, op. 468, d. 2990, Doklady, 11. 49-5I, draft note to the resident minister in Hamburg Struve approved by Alexander (8 May i 820$)$. 
48. The relevant articles promised allied assistance for German princes trying to arrange land swaps. Russian interest in the rights of German sovereigns had been evident already at the Congress of Vienna. See RGADA, f. I5, op. I, d. 533, Alexander's instructions of $3 / 15$ February i8Is to Russia's first plenipotentiary at the Congress of Vienna, Count Andrei K. Razumovskii.

49. During the years I805-I5, Hessen-Homburg was mediatized into Hessen-Darmstadt.

50. On this subject, see Thomas Nipperdey, Germany from Napoleon to Bismarck, 1800-I866, trans. Daniel Nolan (Princeton, NJ: Princeton University Press, 1996).

5I. In I8I5 Berg became a province of Prussia (Rheinprovinz).

52. $V P R$, v. 2 (I0), doc. 33 (6/18 December 1817), pp. 104-9, Nesselrode to envoy in Dresden V. V. Khanykov. The Grand Duchy of Saxony-Weimar-Eisenach, known for its liberal government, was established in 1815 and became part of Thuringia in 1920. Köbler, Historisches Lexikon, 532.

53. Although the Russian government refrained from public criticism of Karl August, the grand duke responded to pressure from Austria and Prussia by strengthening censorship and initiating judicial proceedings against professors at the University of Jena. $V P R$, v. 2 (Io), n. 46, p. 750.

54. VPR, v. 2 (I0), doc. 20 (17/29 November 1817), pp. 68-69, Nesselrode to Anstett; doc. 3I (3/15 December 1817), pp. 98-100, Nesselrode to Stackelberg; doc. 33 (6/18 December I8I7), pp. I04-9, Nesselrode to Khanykov; doc. 39 (2I December I8I7/2 January I8I8), pp. I23-25, Stackelberg to Nesselrode.

55. The assassin, Karl Sand (1795-1820), viewed the murder as a call to revolutionary action and was executed for his crime. On Sand, the threat of radicalism, and the Karlsbad Decrees, see Wolfram Siemann, Metternich: Strategist and Visionary, trans. Daniel Steuer (Cambridge, MA: Harvard University Press, 2019), Kindle edition, 567-60I.

56. James J. Sheehan, German History $1770-1866$ (New York: Oxford University Press, 1989), 406-8, 449-50; Stefan Rohrbacher, "Hep-Hep Riots (1819)," in Antisemitism: A Historical Encyclopedia of Persecution, ed. Richard S. Levy, 2 vols. (Santa Barbara, CA: ABC-CLIO, 2005), i: 297-98.

57. For Aleksandr S. Sturdza's analysis of why the German Confederation could not succeed, see RGADA, f. 3, op. I, d. 78, Reports and correspondence of Sturdza to Kapodistrias, 11. 153-95. Writing to Kapodistrias in February and March I820, Sturdza highlighted his wish, in light of the conferences in Vienna, to provide the ministry with good ideas that invited reflection.

58. In July I 820 a meeting of German ministers accepted a revised federal constitution that limited discussion of liberal policies (Jewish emancipation, religious toleration, and economic reform), reinforced restrictions on changes to federal and state institutions, allowed the confederation to intervene in the domestic affairs of federated states to preserve order (article 26), and prohibited German sovereigns from accepting constitutions that hampered the fulfilment of obligations to the confederation (article 58). According to James Sheehan, plans of $182 \mathrm{I}-22$ for a federal military policy and wartime army had little practical effect, and from $1819-20$ onward, "the German Confederation moved 
to the fringes of national life." In I 820 this was not yet apparent to the peacemakers of Europe. Sheehan, German History, 391-425. On Metternich's concerns about the spread of revolution, especially if Prussia adopted a constitution, see the report from Russia's ambassador in Berlin, David M. Alopeus, to Nesselrode: $V P R$, v. 3 (II), doc. 23 (19/31 July I819), pp. 77-80. In July I820, the Prussian government described the country as politically calm. AVP RI, f. I33, op. 468, d. 2992, Doklady, 11. 284-86. On German constitutionalism, see Markus J. Prutsch, Making Sense of Constitutional Monarchism in Post-Napoleonic France and Germany (London: Palgrave Macmillan, 2013); Morten Nordhagen Ottosen, "The Practical Politics of Restoration Constitutionalism: The Cases of Scandinavia and South Germany," in A History of the European Restorations. Volume I: Governments, States and Monarchy, ed. Michael Broers and Ambrogio A. Caiani (London: Bloomsbury Academic, 2020), I: I2I-31; Georg Eckert, "Royal Opposition against the Ancien Régime: The Case of Württemberg," in Broers and Caiani, European Restorations, I: $133-43$.

59. $V P R$, v. 3 (II), doc. 5 (8/20 May I819), pp. 19-20, Nesselrode to Alopeus; doc. II (3/15 June I819), pp. 35-36, dispatch from Nesselrode to Khanykov (an identical dispatch was sent to Anstett); doc. 23 (19/3I July I819), pp. 77-80, Alopeus to Nesselrode; doc. 44 (6/18 October 1819), pp. 136-37, Kapodistrias to Alopeus. In a letter of 4/16 October I8I9 to Emperor Francis of Austria, Alexander expressed support for the measures adopted in Frankfurt (the Karlsbad Decrees). VPR, v. 3 (II), doc. 43, pp. 134-35. Additional documents describing the Russian response to the Karlsbad Decrees can be found in RGADA, f. I5, op. I, d. 279, 11. 144-84ob. These documents, all confirmed in November and early December I819, include circular letters to Russia's ministers in Germany, a memorandum presenting Emperor Alexander's thoughts on German affairs, and a dispatch to Count Lieven. On the refusal to comment publicly on constitutional debates and reforms inside German states, see $V P R$, v. 3 (II), doc. 67 (30 November/I2 December I819), pp. 190-92, Nesselrode to Pahlen; doc. 89 (4/16 February i820), pp. 256-57, Nesselrode to envoys Alopeus (Berlin), Anstett (Frankfurt), Golovkin (Vienna), P. B. Kozlovskii (Stuttgart and Karlsruhe), and Pahlen (Munich). On the continuation of moderate policies, despite concern about the impact of harmful ideas on Russian students attending German universities, see Alexander's orders of II $/ 23$ November I 820 sent from Troppau to minister of internal affairs Count Viktor P. Kochubei (I768-I834). AVP RI, f. 133, op. 468, d. 2990, Doklady, 1l. 79-82.

60. Genrikh A. Struve's dispatch of I/13 July I820 illustrates the ongoing support for moderate constitutional government. Struve wrote this report after the outbreak of revolution in Spain and the Kingdom of the Two Sicilies. AVP RI, f. 133, op. 468, d. 2992, Doklady, 11. 253-540b.

6I. See Alexander's letter of 4/16 October 1819 to Francis I and Kapodistrias's dispatch of 6/18 October 1819 to Alopeus. $V P R$, v. 3 (II), doc. 43, pp. 134-35; doc. 44, pp. I36-37. On discussions with Britain, see $V P R$, v. 3 (II), doc. 55 (22 November/4 December I819), pp. 163-66, Nesselrode to Lieven; doc. 90 (4/16 February 1820), pp. 257-62, Nesselrode to Alopeus; doc. 103 (3/15 March 1820), pp. 318-20, Nesselrode to Lieven; RGADA, f. I5, op. I, d. 279, 11. I80-840b., dispatch of 22 November/4 December I8I9 to 
Lieven with a copy of the instruction to ministers in Germany and the thoughts of the emperor on the situation in Germany. On the harmful consequences of the Karlsbad Decrees, see the confidential letter from Kapodistrias to Austria's envoy in Saint Petersburg Ludwig Joseph Lebzeltern: $V P R$, v. 3 (II), doc. 66 (30 November/ı2 December I819), pp. I88-90. See also the overview of Alexander's ideas on German affairs: $V P R, \mathrm{v}$. 3 (II), doc. 54 (2r November/3 December I8I9), pp. 153-62; RGADA, f. I5, op. I, d. 279, 11. I55-710b. Finally, see the subsequent instructions from the Ministry of Foreign Affairs to Russia's diplomats serving abroad, which reiterated the policy of non-interference in German affairs, including pronouncements on the Karlsbad Decrees, and stressed that only through the use of moral force could governments ensure the well-being of peoples: $V P R$, v. 3 (II), doc. 73 (23 December I819/4 January I820), pp. $205-10$.

62. $V P R$, v. 3 (II), doc. 54 (2I November/3 December I8I9), pp. 153-62; RGADA, f. I5, op. I, d. 279, 11. I55-710b.

63. VPR, v. 3 (II), doc. 67 (30 November/12 December 1819), pp. 190-92, Nesselrode to Pahlen.

64. For a summary treatment and bibliography on this subject, see Elise Kimerling Wirtschafter, Russia's Age of Serfdom 1649-186I (Malden, MA: Blackwell Publishing, 2008), chaps. 5, 8. For recent Russian studies, see S. V. Mironenko, Aleksandr I $i$ dekabristy: Rossiia v pervoi chetverti XIX veka; Vybor puti (Moscow: Kuchkovo pole, 2017); Mariia Maiofis, Vozzvanie k Evrope: Literaturnoe obshchestvo "Arzamas" i rossiiskii modernizatsionnyi proekt I8I5-I8I8 godov (Moscow: Novoe literaturnoe obozrenie, 2008).

65. $V P R$, v. 3 (II), doc. 54 (2I November/3 December I819), pp. 156-57.

66. On the idealized patriarchal household, see Elise Kimerling Wirtschafter, The Play of Ideas in Russian Enlightenment Theater (DeKalb: Northern Illinois University Press, 2003), chap. 3; Carolyn Johnston Pouncy, ed. and trans., The Domostroi: Rules for Russian Households in the Time of Ivan the Terrible (Ithaca, NY: Cornell University Press, 1994).

67. $V P R$, v. 3 (II), doc. 88 (4/16 February 1820), pp. 250-56, Nesselrode to Alopeus, Anstett, Golovkin, Kozlovskii, and Pahlen; doc. 90 (4/16 February I820), pp. 257-62, Nesselrode to Alopeus; doc. 91 (10/22 February 1820), pp. 262-64, Pozzo di Borgo to Nesselrode.

68. $V P R$, v. 3 (II), doc. 90 (4/16 February I820), pp. 257-62, Nesselrode to Alopeus; doc. I20 (4/16 May I820), pp. 38I-83, Lieven to Nesselrode.

69. RGADA, f. 3, op. I, d. 78, 1l. 104-23ob., 348ob.-50. Sturdza, with the assistance of his "collaborateur" Baron Brunness, produced several analyses of German affairs in which he criticized the underlying principles of the German Confederation and the protocols of the Vienna conferences where discussion of constitutional reform (which eventually led to the Schlussakte) was ongoing. Sturdza argued that the German Confederation was fundamentally incompatible with the general alliance of European states, suggested that Germany's collective federal existence could only come about through the restoration of imperial power (a reference to the Holy Roman Empire abolished by Napoleon in 1806), and criticized the Karlsbad Decrees for banning subversive political speech but not blasphemy or attacks on religion. The politics of nations, Sturdza insisted, 
could not be separated from their morality, by which he meant Christian morality. According to Sturdza, the effort to achieve a united Germany was bound to fail. RGADA, f. 3, op. I, d. 78 , 11. 153-95.

70. Alexander M. Martin, Romantics, Reformers, Reactionaries: Russian Conservative Thought and Politics in the Reign of Alexander I (DeKalb: Northern Illinois University Press, 1997); Stella Ghervas, Réinventer la tradition: Alexandre Stourdza et l'Europe de la Sainte-Alliance (Paris: Honoré Champion, 2008).

71. Alexander decided not to discuss constitutional principles in Aix-la-Chapelle, because he realized that the mass of Russian nobles opposed both constitutional projects and the abolition of serfdom. Maiofis, Vozzvanie k Evrope, 24-26. Equally noteworthy, historians distinguish between old regime and modern constitutions. Modern constitutions such as those of the American and French revolutions of the late eighteenth century represented "the fundamental law of the state from which the legislative, executive and judicial authority of the government derives." Modern constitutions define "the relationship of the government and the governed" and guarantee the "civil rights' of individuals." Old regime constitutions corresponded to the "body of laws, regulations and customs by which a state is governed." The semantic confusion of the early nineteenth century explains why individual and official attitudes toward constitutions sometimes seemed inconsistent. Janet M. Hartley, “The 'Constitutions' of Finland and Poland in the Reign of Alexander I: Blueprints for Reform in Russia?" In Finland and Poland in the Russian Empire: A Comparative Study, ed. M. Branch, J. Hartley, and A. Maczak (London: School of Slavonic and East European Studies, University of London, 1995), 4I-59, here 4I-42.

72. RGADA, f. 3, op. I, d. 162, 11. 40-420b., 72-730b., sessions of I3, 20, 21 November.

73. See the Treaty of Alliance of $14 / 26$ September I8I5 and the Russian government's memorandum of 26 September/8 October 1818, submitted to the ministers of Austria, Britain, and Prussia.

74. VPR, v. 2 (10), doc. 96 (4/16 April I818), pp. 297-304, here p. 301, Golovkin to Kapodistrias.

\section{Chapter 3: Alliance Unity and Intervention in Naples (I820-2I)}

I. $V P R$, v. 3 (II), n. 227 , pp. $78 \mathrm{I}-83$.

2. On Germany, see $V P R$, v. 3 (II), doc. 196 (26 November/8 December I820), pp. 635-44, instruction from Nesselrode to Major General Konstantin Khristoforovich Benkendorf. For Russian evaluations of political conditions in France, see $V P R$, v. 3 (II), doc. 7 (8/20 May I819), pp. 23-27, personal letter from Nesselrode to Kapodistrias; doc. I3 (8/20 June I819), pp. 38-39, Nesselrode to Lieven; doc. I9 (5/17 July 1819), pp. 53-55, report from Nesselrode to Alexander; doc. 20 (15/22 July i819), pp. 55-77, report from Kapodistrias to Alexander; doc. I28 (29 May/ıo June I820), pp.408-II, Pozzo di Borgo to Nesselrode. For Russian efforts to organize a common allied communication on French politics addressed to Louis XVIII, see $V P R$, v. 3 (II), doc. 25 (26 July/7 August I8I9), pp. 8I-84, Nesselrode to Lieven; doc. 32 (I2/24 August I8I9), pp. 94-I04, 
memorial memorandum of Kapodistrias; doc. 56 (22 November/4 December I819), pp. 166-72, memorial memorandum from the Russian cabinet to the governments of Austria, Britain, and Prussia. On French fears about Austria’s plans to intervene in Italy and Russia's effort to reassure France that Austria did not seek conquest, see $V P R$, v. 3 (II), doc. 158 (25 August/6 September I820), p. 496, confidential letter from Kapodistrias to Pozzo di Borgo.

3. The Duke of Richelieu replaced Charles Maurice de Talleyrand as head of the French government in September I8I5, following the electoral victory of the ultra-royalists. Richelieu also had been in Russian service, with interruptions, during the years I790 to I8I 4 and enjoyed Emperor Alexander's trust. The duke's resignation in December 1818 resulted from the ascendance of Minister of Police Élie Decazes, a centrist known for his efforts to accommodate liberals. Decazes did not formally become head of the government until after elections in the fall of 1819 , which increased the power of independents. Following the assassination of Louis XVIII's nephew, the Duke of Berry, on the night of $13-14$ February 1820 , the king dismissed Decazes and replaced him with Richelieu. But Richelieu again resigned in December I821, due to radical and ultra-royalist opposition. G. de Bertier de Sauvigny, "French Politics, I814-47," in The New Cambridge Modern History. Vol. 9: War and Peace in an Age of Upheaval, 1793-1830, ed. C. W. Crawley (Cambridge: Cambridge University Press, 1965), 340-49. Allied concern about political stability in France continued into I822. See $V P R$, v. 4 (I2), doc. 49 (23 January/4 February I822), pp. 4I 4-I8, Nesselrode to Pozzo di Borgo; AVP RI, f. I33, op. 468, d. 2992, Doklady, 1. 2-1 Iob., summary of reports received from Russia's missions abroad from the end of last year to the present day (30 March 1820 ).

4. Charles IV of Spain (ruled 1788-1808) was the great-grandson of Louis XIV, brother to Ferdinand I of the Kingdom of the Two Sicilies, and father to Ferdinand VII of Spain. Richard Stites, The Four Horsemen: Riding to Liberty in Post-Napoleonic Europe (New York: Oxford University Press, 2014), Kindle edition, chap. I.

5. Stites, Four Horsemen, chap. 2.

6. The king fled to Brazil after France invaded Portugal in November 1807; he returned to Lisbon in ${ }_{182} \mathrm{I}$ in response to Portuguese and British pressure. Brazil became independent in 1822. Stites, Four Horsemen, location 2167-74; R. A. Humphreys, "The Emancipation of Latin America," in Crawley, New Cambridge Modern History, 612-38.

7. At the Congress of Vienna, Ferdinand IV of Naples and III of Sicily became Ferdinand I of the Kingdom of the Two Sicilies. Stites, Four Horsemen, chap. 3; J. M. Roberts, "Italy, 1793-I830," in Crawley, New Cambridge Modern History, 412-38.

8. Nor did ongoing negotiations about allied intervention prevent further revolutionary outbreaks. Following an insurrection in the Kingdom of Sardinia (Sardinia-Piedmont) on 9/10 March I82I, a provisional government proclaimed the Spanish constitution of I8I2, and the Sardinian king, Victor Emmanuel I, abdicated in favor of his brother, Charles Felix. Charles Felix then fled to Laibach to appeal to the great powers. Austria intervened, and the revolution ended within a month. Stites, Four Horsemen, location $4200-15$. 
9. $V P R$, v. 3 (II), doc. 56 (22 November/4 December I8I9), pp. 166-72, memorial memorandum from the Russian cabinet to the governments of Austria, Britain, and Prussia; doc. 73 (23 December I819/4 January 1820), pp. 205-10, memorandum of instruction from the Ministry of Foreign Affairs to Russia's diplomatic representatives abroad.

Io. The meetings between Castlereagh, Kapodistrias, and Lieven took place in London in August I819. For the memorandum of 24 September I819, see $V P R$, v. 3 (II), n. 75 , p. 74I. On Castlereagh's diplomacy and British policy with respect to Naples, see John Bew, Castlereagh: A Life (New York: Oxford University Press, 2012), chap. 16.

II. $V P R$, v. 3 (II), doc. 32 (I2/24 August I819), pp. 94-104, memorial memorandum of Kapodistrias; doc. 56 (22 November/4 December I819), pp. 166-72, memorial memorandum from the Russian cabinet to the governments of Austria, Britain, and Prussia. See also $V P R$, v. 3 (II), doc. 25 (26 July/7 August I8I9), pp. 8I-84, Nesselrode to Lieven.

I2. $V P R$, v. 3 (II), doc. 56 (22 November/4 December 1819), pp. 166-72, memorial memorandum from the Russian cabinet to the governments of Austria, Britain, and Prussia.

I3. $V P R$, v. 3 (II), doc. 73 (23 December I819/4 January I820), pp. 205-10, memorandum of instruction from the Ministry of Foreign Affairs to Russia's diplomatic representatives abroad.

I 4. On the assassination of the Duke of Berry, see also AVP RI, f. I33, op. 468, d. 2992, Doklady, 1l. I2 I-23ob.

I5. $V P R$, v. 3 (II), doc. 96 (February I820), pp. 274-85, memorandum of Obreskov.

16. AVP RI, f. 133, op. 468, d. 2992, Doklady, 1. 159ob., summary of dispatch from Mr. Anstett submitted to the emperor.

17. RGADA, f. 3, op. I, d. 78, Reports and correspondence from Sturdza to Kapodistrias, 1l. 325-270b., 345ob.-48. Sturdza's role is confirmed by Alexander M. Martin, who discusses the review in Romantics, Reformers, Reactionaries: Russian Conservative Thought and Politics in the Reign of Alexander I (DeKalb: Northern Illinois University Press, 1997), 176-79. See also Stella Ghervas, Réinventer la tradition: Alexandre Stourdza et l'Europe de la Sainte-Alliance (Paris: Honoré Champion, 2008); Elise Kimerling Wirtschafter, "Russian Perspectives on European Order: 'Review of the Year I819,'” in Russia and the Napoleonic Wars, ed. Janet M. Hartley, Paul Keenan, and Dominic Lieven (New York: Palgrave Macmillian, 2015), 57-69.

I8. The review was divided into two parts. The first, dated I2 December 1819, covered the international political events of the year, and the second, dated I 4 January I820, covered political divisions and ideologies in Europe. The document located in RGADA contains only part I. Martin briefly discusses the contents of part 2 in Romantics, 175-79.

19. The Congress of Vienna had outlawed the slave trade in principle, and the British government, which had made the trade illegal in 1807 , used its naval power to search suspect vessels at sea. Unilateral British action ended after British courts in the Le Louis judgment of 1817 rejected the right of the Royal Navy to stop and search the slaving ships of powers that had not requested assistance. The reference to Sweden and Denmark concerned Sweden's refusal to accept responsibility for Norway's debt. By a treaty of I8I5 Denmark had received the Duchy of Lauenburg in return for Swedish Pomerania, which Prussia then purchased from Sweden. According to Schroeder, the territorial settlement 
between Denmark and Sweden, mediated by Russia, marked the end of the Northern Question and the beginning of a tradition of Swedish neutrality comparable to that of Switzerland. At this time also, the Norwegians submitted to Swedish rule, and at the Congress of Aix-la-Chapelle, the sovereigns collectively addressed the Swedish monarch concerning Sweden's responsibility for the Norwegian debt. Reportedly, under British mediation, the contracting parties resolved the dispute with a convention concluded in Copenhagen on i September I819. Brendan Simms, Europe: The Struggle for Supremacy, from 1453 to the Present (New York: Basic Books, 2013), I68, I8I-88; Paul W. Schroeder, The Transformation of European Politics $176_{3}-1848$ (New York: Oxford University Press, 1994), 572, 578, 766-67; VPR, v. 3 (II), doc. 73 (23 December I819/4 January I820), pp. 205-10, memorandum of instruction from the Ministry of Foreign Affairs to Russia's diplomatic representatives abroad; n. 78 , p. 742.

20. Concern about instability in France led in I818 to a final settlement on reparations and to the early withdrawal of allied occupation forces. In 1817 the Bourbon government had introduced a constitutional charter with a franchise restricted to 100,000 voters. Although Bonapartist and royalist deputies remained critical of the government's willingness to accept allied interference in France's domestic politics, the Bourbons adhered to the terms of the Vienna settlement and resisted popular pressure to pursue a more aggressive foreign policy. Simms, Europe, 185-86.

21. For discussion of Sturdza's i818 Mémoire sur l'état actuel de l'Allemagne, see Ghervas, Réinventer, 202-17.

22. The attacks on Jews likewise caused Metternich to conclude that Germany lacked security. James J. Sheehan, German History 1770-1866 (New York: Oxford University Press, 1989), 407-8, 449-50.

23. Instructions of 23 December I819/4 January 1820, sent to Russia's diplomats abroad, concluded that the German unity represented by the Karlsbad/Frankfurt decrees of 20 September I8I9 had proven illusory. The instructions ordered Russia's ministers in Germany not to support a specific policy or participate in German politics. VPR, v. 3 (II), doc. 73 (23 December I819/4 January I820), pp. 205-10.

24. Another issue being discussed at the time Sturdza wrote the review was the dispute between Spain and Portuguese Brazil over the Rio de la Plata. Related to this was the commercial liberty of the Spanish colonies. A conference in Paris tried to mediate these questions. $V P R$, v. 3 (II), doc. 73 (23 December I819/4 January I820), pp. 205-IO, memorandum of instruction from the Ministry of Foreign Affairs to Russia's diplomatic representatives abroad.

25. The agreement with Spain ended the legal importation of slaves into Spain proper; however, Spanish involvement in the international slave trade continued. Nor did Portuguese involvement in the transatlantic slave trade end. Simms, Europe, 199-200; VPR, v. 3 (II), doc. 73 (23 December 1819/4 January I820), pp. 205-10, memorandum of instruction from the Ministry of Foreign Affairs to Russia's diplomatic representatives abroad.

26. Diplomatic conferences in London addressed the abolition of the slave trade and repression of the Barbary states. In addition, plenipotentiaries meeting in Aix-la-Chapelle authorized Britain and France to organize a mission to resolve the problem of the 
Barbary states. Instructions of 23 December I819/4 January I820, sent to Russia's diplomats abroad, indicated that to date the efforts had not produced results. VPR, v. 3 (II), doc. 73 (23 December 1819/4 January 1820), pp. 205-10, memorandum of instruction from the Ministry of Foreign Affairs to Russia's diplomatic representatives abroad.

27. Selim III (176I-I808) ruled as sultan from 1789 to 1807 . He supported European-style military organization and training; the reform of Ottoman administration, taxation, and land tenure; and the development of direct diplomatic contacts with Europe. Selim's reforms triggered rebellion among Janissaries and provincial notables, which led to his imprisonment and assassination.

28. The current order of things referred to Ottoman and Persian relationships with the neighboring Christian powers, Russia and Austria, that had been codified in the treaties of Sistova (I79I), Jassy (I792), Bucharest (I8I2), and Gulistan (I813). Sturdza also expressed concern about the British protectorate over the Ionian Islands, an arrangement that Russia had encouraged (and Kapodistrias supported) in order to prevent Austrian control, which would have represented a significant barrier to Russian policy in the Balkans and to Greek national aspirations. Schroeder, Transformation, 86-87, 572-74; Thomas Sanders, Ernest Tucker, and Gary Hamburg, eds., Russian-Muslim Confrontation in the Caucasus: Alternative Visions of the Conflict between Imam Shamil and the Russians, 1830-1859 (New York: RoutledgeCurzon, 2004).

29. $V P R$, v. 3 (II), doc. 102 (3/15 March I820), pp. 315-18, Nesselrode to Lieven.

30. $V P R$, v. 3 (II), doc. Io8 (30 March/ı April I820), pp. 337-43, memorandum from Kapodistrias to Alexander; RGADA, f. 3, op. I, d. 78, 1l. 28I-99ob.; AVP RI, f. I33, op. 468, d. 2992, Doklady, 1l. 2-IIob., summary of reports received from Russia's missions abroad from the end of last year to the present day (30 March I820); 11. I2-I 4ob., follow-up to the possible courses of action indicated in the agenda of 30 March (6 April I820). Emperor Alexander also continued to communicate to the allies the need for collective action. VPR, v. 3 (II), doc. II3 (I9 April/I May I820), pp. 35I-53, Nesselrode to Golovkin, Lieven, and Alopeus.

31. Electoral reforms limiting the franchise took place in June i820. AVP RI, f. I33, op. 468, d. 2992, Doklady, 1. 2ob., summary of reports received from Russia's missions abroad from the end of last year to the present day (30 March 1820 ).

32. The Spanish viceroyalty of Rio de la Plata included present-day Argentina, Uruguay, Paraguay, and Bolivia. Rebellion began in the viceroyalty in I810, and north of the Rio de la Plata, Spain and Portugal competed for territory. In I8I5 the Portuguese colony of Brazil became a kingdom, and in 1816 Portuguese Brazil extended its frontier all the way to the river. European efforts to mediate the conflict had not succeeded. Humphreys, "Latin America," 6I 4-2I.

33. AVP RI, f. 133, op. 468, d. 2992, Doklady, 1l. 236-370b., dispatch from Pozzo di Borgo (27 July I820). See also the review of events during I820, up to the month of August, sent by Sturdza to Kapodistrias on 19 September/I October 1820. RGADA, f. 3, op. I, d. 78, 11. 28I-99ob.

34. In modern parlance, George IV sought a divorce. On sedition in Britain and its relationship to economic, social, and political conditions, see Lieven's report to Nesselrode 
in $V P R$, v. 3 (II), doc. 87 (2/14 February I820), pp. 24I-50. On the case against the queen, see the report from Nesselrode to Alexander and the dispatches from London (all from July i820) summarized in AVP RI, f. I33, op. 468, d. 2992, Doklady, 11. 238-45, 24748ob., 252-520b., 265-65ob.; Bew, Castlereagh, chap. I5.

35. AVP RI, f. I33, op. 468, d. 2992, Doklady, 11. 236-37ob., dispatch from Pozzo di Borgo (27 July I820). From mid-July until late August, Russia's Ministry of Foreign Affairs received a steady stream of reports on the revolution in Naples and revolutionary developments in other parts of Italy. British policy accepted Austria's special interest in the Kingdom of the Two Sicilies but opposed allied intervention. AVP RI, f. 133, op. 468, d. 2992, Doklady, 1l. 293-3010b., 303-6, 324-250b., 338-50ob., reports from Nesselrode to Alexander summarizing dispatches from Naples and Florence (covering the period from 17 July to 24 August 1820).

36. The Prussian government acknowledged that Britain would not accept Austria's proposals for intervention. AVP RI, f. I33, op. 468, d. 2992, Doklady, 1l. 284-86, dispatch of $20 \mathrm{July} / \mathrm{I}$ August 1820 received from Berlin.

37. The Troppau conferences continued until I2/24 December I820. O. V. Orlik, Rossiia v mezhdunarodnykh otnosheniiakh I8IS-I829: Ot Venskogo kongressa do Adrianopol'skogo mira (Moscow: Nauka, 1998), 38-45; Schroeder, Transformation, 607-14; Henry A. Kissinger, A World Restored: Metternich, Castlereagh and the Problems of Peace, I8I2-I822 (Boston: Houghton Mifflin Company, 1957), 256-66; Jennifer Mitzen, Power in Concert: The Nineteenth-Century Origins of Global Governance (Chicago: University of Chicago Press, 2013), I02-23. Christian Gunther Bernstorff (1769-1835) served as Prussian minister of foreign affairs in I818-31.

38. On Alexander's conservative turn and opposition within Russian society to Austrian intervention in Naples, see M. A. Dodolev, "Russia and the Spanish Revolution of 1820-1823," Soviet Studies in History 8, no. 3 (Winter 1970): 252-71. For recent treatment of Alexander's conservatism and continuing interest in constitutional reform, see Patrick O'Meara, The Russian Nobility in the Age of Alexander I (London: Bloomsbury Academic, 2019), chap. 8.

39. AVP RI, f. I33, op. 468, d. 2992, Doklady, 1. 189, communications about a meeting between Alexander and Francis (May-June I820).

40. $V P R$, v. 3 (II), doc. I29 (2/I4 June I820), p. 4II, Stackelberg to Nesselrode; doc. I3I (2/I 4 June I820), pp. 4I4-I5, Nesselrode to Golovkin; doc. I4I (24 June/6 July i820), pp. 434-36, Stackelberg to Nesselrode; doc. I 46 (I5/27 July 1820), pp. 450-52, personal letter from Nesselrode to Golovkin; doc. I52 (3/15 August 1820), pp. 475-76, chargé d'affaires in Florence A. V. Sverchkov to Nesselrode; doc. 155 (17/29 August I820), pp. 482-85, Golovkin to Kapodistrias; doc. 156 (2I August/2 September 1820), pp. 485-91, Kapodistrias to Stackelberg; doc. 171 (26 September/8 October 1820), pp. 532-33, Stackelberg to Kapodistrias. On 3 August 1820 Nesselrode reported to Alexander that Austria continued to seek a private meeting between him and Francis that would not include the Prussian monarch. France had proposed a general meeting of the sovereigns, and Britain had not yet offered a precise response because of preoccupation with the trial of the queen. AVP RI, f. 133, op. 468, d. 2992, Doklady, 1l. 303-6, report from Nesselrode to Alexander (3 August i820). 
4I. $V P R$, v. 3 (II), n. 260 , p. 798.

42. $V P R$, v. 3 (II), n. 212, pp. 776-77. In dispatches of $3 / 15$ and 7/19 August 1820 , Count Iurii A. Golovkin, Russia's envoy in Vienna, reported on the deployment of Austrian troops to the Kingdom of Lombardy-Venetia. Golovkin's implied recognition of Austria's special interest in Italy did not prevent him from attributing the poor condition of the Austro-Italian provinces to "the vices" of Austrian administration. AVP RI, f. I33, op. 468, d. 2992, Doklady, 11. 28-320b., summary of dispatches received from Golovkin (3/15 and 7/19 August), Italinskii (28 July/ır August), Alopeus (I2 August), and Anstett (no date given) since the departure of H. I. M. from Poltava (17/29 August 1820).

43. AVP RI, f. I33, op. 468, d. 2992, Doklady, 1l. 28-320b., summary of dispatches received since $17 / 29$ August 1820 .

44. In the dispatches of $3 / 15$ and $7 / 19$ August 1820 , Golovkin also reported on British support for swift Austrian action in Naples. On 24 August Nesselrode confirmed that Britain deferred to Austria on the measures to be taken in Naples and therefore communicated directly with the court of Vienna on the matter. See AVP RI, f. 133, op. 468, d. 2992, Doklady, 1l. 28-32ob., summary of dispatches received since 17/29 August I820; 11. 339-440b., report from Nesselrode to Alexander (24 August i820).

45. VPR, v. 3 (II), doc. I5I (2/I 4 August I820), pp. 468-75, Lieven to Nesselrode; doc. I63 (6/18 September I820), pp. 504-6, personal letter from Kapodistrias to Lieven; doc. 164 (I2/24 September 1820), pp. 506-I 4, Lieven to Kapodistrias; AVP RI, f. I33, op. 468, d. 2992, Doklady, 1l. 28-320b., summary of dispatches received since 17/29 August I820; 11. 339-440b., report from Nesselrode to Alexander (24 August i820).

46. VPR, v. 3 (II), doc. I56 (2I August/2 September 1820), pp. 485-91, Kapodistrias to Stackelberg.

47. $V P R$, v. 3 (II), doc. 156 (2I August/2 September 1820), pp. 485-9I, Kapodistrias to Stackelberg. In a dispatch of 28 July/ı August ı 820 , Andrei I. Italinksii, Russia’s envoy in Rome, reported that due to "national hatred" of Austrians in Italy, fear of an Austrian intervention prevented insurrection in the papal states. AVP RI, f. I33, op. 468, d. 2992 , Doklady, 1l. 28-32ob.

48. $V P R$, v. 3 (II), doc. 170 (23 September/5 October 1820 ), pp. 527-32, letter from Kapodistrias to Sturdza. The language of contagion appeared in numerous documents: see the report of 19 September/I October 1820 from Sturdza to Kapodistrias, in RGADA, f. 3 , d. 78 , 11. 279-8oob.

49. $V P R$, v. 3 (II), doc. 175 (5/17 October I820), pp. 540-47; AVP RI, f. 133, op. 468, d. 2992, Doklady, 1l. 374-84ob., agenda read to Alexander by Kapodistrias on the works in Troppau.

50. For drafts of agendas, protocols, notes, opinions, observations, and memorandums from the conferences in Troppau, see RGADA, f. 3, op. I, d. 6I, On the political conferences in Troppau (October-December 1820).

51. $V P R$, v. 3 (II), doc. 177 (I $4 / 26$ October I820), pp. 555-62, report from Kapodistrias and Nesselrode to Alexander; doc. 178 (15/27 October I820), pp. 562-66, report from Kapodistrias and Nesselrode to Alexander; AVP RI, f. 133, op. 468, d. 2992, Doklady, 11. 
385-930b., 4II-24, reports from Kapodistrias and Nesselrode on confidential meetings with Metternich in Troppau (I5/27 and 16/28 October 1820).

52. VPR, v. 3 (II), doc. 177 (I 4/26 October 1820), pp. 555-62, report from Kapodistrias and Nesselrode to Alexander; AVP RI, f. I33, op. 468, d. 2992, Doklady, 1l. 4II-24, report from Kapodistrias and Nesselrode to Alexander.

53. VPR, v. 3 (II), doc. 178 (I5/27 October I820), pp. 562-66, report from Kapodistrias and Nesselrode to Alexander.

54. AVP RI, f. 133, op. 468, d. 2992, Doklady, 11. 395-97, report from Kapodistrias and Nesselrode to Alexander on the position of Austria (is October i820).

55. AVP RI, f. 133, op. 468, d. 2992, Doklady, 11. 405-10, Austrian proposal for a treaty of guarantee.

56. VPR, v. 3 (II), doc. 179 (24 October/5 November 1820 ), pp. 567-72, memorandum from Kapodistrias and Nesselrode to Alexander; doc. I80 (24 October/s November I820), pp. 572-76, memorandum from Kapodistrias and Nesselrode to Alexander; AVP RI, f. I33, op. 468, d. 2992, Doklady, 11. 429-45, reports from Kapodistrias and Nesselrode to Alexander on the execution of the plans for Naples agreed to in Troppau ( 24 October/s November I820).

57. $V P R$, v. 3 (II), doc. 179 (24 October/s November I820), pp. 567-72, memorandum from Kapodistrias and Nesselrode to Alexander; AVP RI, f. 133, op. 468, d. 2992, Doklady, 11. 429-37, report from Kapodistrias and Nesselrode to Alexander 24 October/s November 1820). In August France had supported a declaration of "the five powers placed at the center of the general alliance." The declaration would have denounced the means employed in Naples to change the administration and would have explained that despite the allies' respect for "the independence of governments," they could not recognize the new administration until such time as "the king and the nation" pronounced freely "on the constitutive laws of the Kingdom.” AVP RI, f. I33, op. 468 , d. 2992, Doklady, 11. 28-320b., summary of dispatches received since $17 / 29$ August 1820 .

58. According to Kapodistrias and Nesselrode, Britain and France had several options. They could become parties to the agreement, postpone their accession, accede only as guarantors of allied obligations to the king of Naples, or participate in negotiations with the king as mediators. $V P R$, v. 3 (II), doc. 179 (24 October/s November I820), pp. 567-72, memorandum from Kapodistrias and Nesselrode to Alexander; AVP RI, f. I33, op. 468, d. 2992, Doklady, 11. 429-37, report from Kapodistrias and Nesselrode to Alexander (24 October/5 November 1820$)$.

59. VPR, v. 3 (II), doc. 180 ( 24 October/5 November 1820), pp. 572-76, memorandum from Kapodistrias and Nesselrode to Alexander; AVP RI, f. 133, op. 468, d. 2992, Doklady, 1l. 438-45, report from Kapodistrias and Nesselrode to Alexander (24 October/5 November 1820).

60. Kapodistrias read the note to Alexander on I6/28 October I820. AVP RI, f. I33, op. 468, d. 2992, Doklady, 1l. 425-28ob., report of Kapodistrias; $V P R$, v. 3 (II), n. 248, p. 79I.

6r. $V P R$, v. 3 (II), doc. I80 (24 October/s November I820), pp. 572-76, memorandum from Kapodistrias and Nesselrode to Alexander; AVP RI, f. 133, op. 468, d. 2992, 
Doklady, 11. 438-45, report from Kapodistrias and Nesselrode to Alexander (24 October/ 5 November I820).

62. On $8 / 20$ November 1820 , the allies agreed to invite the king of the Two Sicilies to meet with them in Laibach, where they planned to reconvene after leaving Troppau. Ferdinand I received the invitation on 6 December 1820 and arrived in Laibach on 7 January I82 I. Stites, Four Horsemen, location 3876-4004; VPR, v. 3 (II), annotations (8/20 November I820), p. 594, Alexander I, Francis I, and Frederick William III to Ferdinand I; Alexander I to Frederick William III.

63. VPR, v. 3 (II), annotation (2I October/2 November 1820), p. 567, response of the Russian cabinet to the communications of the Austrian and Prussian cabinets presented

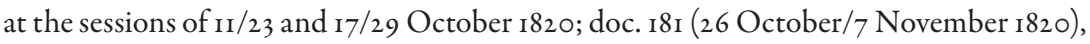
pp. 577-78, memorandum of the Russian court concerning Metternich's proposals of 17/29 October; n. 240, p. 787; n. 245, p. 789; n. 253, pp. 794-97.

64. VPR, v. 3 (II), doc. I84 (2/14 November I820), pp. 585-87, memorandum of Russia's plenipotentiaries.

65. $V P R$, v. 3 (II), doc. 186 (7/19 November 1820), pp. 589-93, preliminary protocol signed by the plenipotentiaries of Russia, Austria, and Prussia.

66. For consistency I use "Neapolitan" rather than "Sicilian" when referring to the situation in Naples and the Kingdom of the Two Sicilies. Documents of the era used both terms.

67. British and Foreign State Papers. Volume 1820-1821 (London, I830), II49-51. The document in State Papers is dated 8 December. See also VPR, v. 3 (II), annotation (24 November/6 December 1820), p. 628. As indicated above, Ferdinand received the invitation to meet with the allies on 6 December. Concerned about the king's ability to leave Naples, the Russian government argued that if the Neapolitan government did not allow Ferdinand to accept the invitation to Laibach, they should seek the mediation of Pope Pius VII. VPR, v. 3 (II), annotations (8/20 November I820), p. 594, Alexander I, Francis I, and Frederick William III to Ferdinand I; Alexander I to Frederick William III; annotation (24 November/6 December 1820), p. 627, opinion of the Russian cabinet on the means of pacification that the allied courts can apply in Naples if the invitation sent to the king is not accepted.

68. Sturdza conveyed his views to Kapodistrias in a report of $5 / 17$ December 1820 . RGADA, f. 3, op. I, d. 78, 11. 311-I7ob.

69. RGADA, f. 3, op. I, d. 78, 11. 357-64ob., Sturdza to Kapodistrias, account of Sturdza's official correspondence from I 4 November I8I9 to I2 December I820, affairs of Naples. For more on Sturdza's views, see $V P R$, v. 3 (II), n. 247, pp. 790-9I.

70. VPR, v. 3 (II), doc. 189 (Io/22 November I820), pp. 602-3, verbal note from Russia's envoy in the Netherlands K. L. Ful' (Karl Ludwig August Phull) to the minister of foreign affairs of the Netherlands Nagel' (Ann William Karl Nagell). Phull (1757-I826) was a Prussian general who entered Russian service in 1806 and served as envoy in the Netherlands in $18 \mathrm{I} 4-2 \mathrm{I}$.

71. $V P R$, v. 3 (II), doc. I9I (II/23 November I820), pp. 608-IO, personal letter from Kapodistrias to Mochenigo. Russia's envoy in Turin was Count G. D. Mochenigo (Mocenigo, $1764-1839)$. 
72. See Nesselrode's instruction to Major General Konstantin Khristoforovich Benkendorff (1783-I828), envoy extraordinaire and minister plenipotentiary to the courts of Württemberg and Baden. VPR, v. 3 (II), doc. 196 (26 November/8 December I820), pp. $635-44$.

73. The memorandum was sent to the minister of internal affairs V. P. Kochubei. $V P R$, v. 3 (II), doc. 194 (19 November/I December I820), pp. 619-27; n. 262, pp. 798-99.

74. The memorandum, authored by Kapodistrias, refused to equate the Austrian proposal with the Russian project for a treaty of guarantee discussed in Aix-la-Chapelle. $V P R$, v. 3 (II), doc. 198 (5/17 December I820), pp. 648-55, memorandum from the Russian government to the governments of Austria and Prussia; n. 253, pp. 795-96.

75. VPR, v. 3 (II), n. 253, pp. 796-97.

76. The documents consulted here include instructions from Nesselrode to Christoph Lieven, Russia's ambassador in London, and reports from Lieven to Nesselrode containing summaries of Lieven's conversations with Castlereagh. $V P R$, v. 3 (II), doc. I82 (28 October/9 November I820), pp. 579-82, Nesselrode to Lieven; doc. 192 (II/23 November I820), pp. 610-13, Nesselrode to Lieven; doc. 193 (I2/24 November I820), pp. 614-19, Nesselrode to Lieven; doc. 195 (26 November/8 December 1820), pp. 628-35, Lieven to Nesselrode; doc. 199 (9/21 December 1820), pp. 655-59, Lieven to Nesselrode. On France's opposition: VPR, v. 3 (II), doc. 202 (15/27 December I820), pp. 665-74, memorandum of the Russian cabinet in response to the comments of France's plenipotentiaries on the preliminary protocol of $7 / 19$ November 1820 ; doc. 203 (15/27 December 1820), pp. 675-76, Kapodistrias to chargé d'affaires in Paris Andrei Andreevich Schröder (1780-?).

77. I develop this point in Elise Kimerling Wirtschafter, From Serf to Russian Soldier. (Princeton, NJ: Princeton University Press, 1990); Elise Kimerling Wirtschafter, Russia's Age of Serfdom, I649-186I (Malden, MA: Blackwell Publishing, 2008).

78. $V P R$, v. 3 (II), doc. I82 (28 October/9 November I820), pp. 579-82, Nesselrode to Lieven.

79. $V P R$, v. 3 (II), doc. 182.

8०. $V P R$, v. 3 (II), doc. I 82 .

8I. $V P R$, v. 3 (II), doc. 192 (II/23 November I820), pp. 6IO-I3, Nesselrode to Lieven.

82. The representatives of Austria and Prussia in London reportedly received comparable instructions.

83. VPR, v. 3 (II), doc. 193 (I2/24 November I820), pp. 614-19, Nesselrode to Lieven.

84. VPR, annotations (8/20 November I820), p. 594, Alexander I, Francis I, and Frederick William III to Ferdinand I; Alexander I to Frederick William III.

85. VPR, v. 3 (II), doc. 193 (I2/24 November I820), pp. 6I 4-19, Nesselrode to Lieven.

86. Bew, Castlereagh, $480-84$.

87. VPR, v. 3 (II), n. 264, pp. 799-800.

88. As reported by Lieven, neither he nor Castlereagh doubted the sincerity or good intentions of the other. $V P R$, v. 3 (II), doc. 195 (26 November/8 December I820), pp. 628-35, Lieven to Nesselrode; doc. 199 (9/21 December 1820), pp. 655-59, Lieven to Nesselrode.

89. VPR, v. 3 (II), doc. 199 (9/21 December 1820), pp. 655-59, Lieven to Nesselrode. 
90. On the political conditions affecting Castlereagh and the British government, see Bew, Castlereagh, 478-517.

9I. Bew, Castlereagh, 478-79. On I3 March I82I Castlereagh wrote to his brother, Charles Stewart, questioning the future of the alliance: "We cannot afford to have our Line in any degree Mixed with that of the Three Powers, and their Endeavor to Impute to us an unity of views, which does not exist, only Embarrasses us and drives us in Parliament into more decisive disavowals." The declaration of the three powers "not to admit of any departure from the Legitimate State of Things" was, according to Castlereagh, "'so odious and so untenable' as to make future cooperation highly problematic." Bew, Castlereagh, 508-9.

92. $V P R$, v. 3 (II), doc. 202 (not later than $15 / 27$ December 1820 ), pp. 665-74, memorandum of the Russian cabinet in response to the comments of France's plenipotentiaries on the preliminary protocol of 7/19 November I820; doc. 203 (15/27 December I820), pp. 675-76, Kapodistrias to Schröder.

93. Charles Louis de Secondat, Baron de Montesquieu, The Spirit of the Laws (1748); Cesare Beccaria, On Crimes and Punishments (1764); Jacob Friedrich Bielfeld, Political Institutions (1765). David M. Griffiths, "Introduction: Of Estates, Charters, and Constitutions," in Catherine II's Charters of 1785 to the Nobility and Towns, ed. and trans. David M. Griffiths and George E. Munro (Bakersfield, CA: Charles Schlacks, Jr., I99I).

\section{Chapter 4: To Act in Concert (I82I-22)}

I. C. A. Bayly, The Birth of the Modern World, 1780-1914: Global Connections and Comparisons (Malden, MA: Blackwell Publishing, 2004), IOI-2. On recuperation, see Paul W. Schroeder, The Transformation of European Politics $1763-1848$ (New York: Oxford University Press, 1994), 586-93. On Napoleon, see Alan Forrest, Napoleon: Life, Legacy, and Image; A Biography (New York: Saint Martin's Press, 2013).

2. Mariia Maiofis, Vozzvanie k Evrope: Literaturnoe obshchestvo "Arzamas" i rossiiskii modernizatsionnyi proekt I8IS-I8I8 godov (Moscow: Novoe literaturnoe obozrenie, 2008), 26-27, 414-15, ch. 8.

3. Leo Tolstoy, War and Peace, trans. Louise Maude and Aylmer Maude (New York: Simon and Schuster, 1942), second epilogue.

4. Close to I13,000 Russian troops marched to three locations in the Austrian Empire, where they were held in reserve. By May it became clear that the troops would not be needed in Italy; however, an army of 123,000 troops remained close to the Austrian border. $V P R$, v. 4 (I2), annotation (3/15 March I82I), p. 47.

5. Austrian troops remained in the Kingdom of the Two Sicilies until December 1826. Richard Stites, The Four Horsemen: Riding to Liberty in Post-Napoleonic Europe (New York: Oxford University Press, 2014), Kindle edition, location 3876-4192; J. M. Roberts, "Italy, 1793-1830," in The New Cambridge Modern History. Vol. g: War and Peace in an Age of Upheaval, $1793-1830$, ed. C. W. Crawley (Cambridge: Cambridge University Press, 1965), 428-35. 
6. RGADA, f. I5, op. I, d. 289, Correspondence of Metternich to Nesselrode, 11. 8-II, confidential letter from Metternich to Nesselrode. For defense of the revolution and constitutional government, written by a liberal observer in Naples, see RGADA, f. I5, op. I, d. 375, Papers of Kapodistrias, 11. 224-4I; d. 377, Papers of Kapodistrias, 11. 28-37. The observer warned that in the short term allied intervention could be materially successful, but in the long term it would lead to renewed social revolution. The two mémoires are preserved in the papers of Kapodistrias. On the false hope that Italian liberals placed in Emperor Alexander, see $V P R$, v. 3 (II), doc. 210 (6/18 January I82I), pp. 695-70I, envoy in Rome A. Ia. Italinskii to Kapodistrias.

7. RGADA, f. 3, op. I, d. 78, Reports and correspondence from Sturdza to Kapodistrias, 11. 319-240b., report no. 59 to Kapodistrias (31 December I820/12 January I82I).

8. Nor did Sturdza's rejection of revolution extend to the Greek insurrection against the Ottoman Empire, which erupted during the meetings in Laibach. Like Kapodistrias, Sturdza opposed Emperor Alexander's policy of neutrality, advocating instead for Russian intervention on behalf of the Greeks as a defense of persecuted coreligionists. Theophilus C. Prousis, Russian Society and the Greek Revolution (DeKalb: Northern Illinois University Press, 1994), 34-38.

9. The Laibach journals are available in AVP RI, f. 133, op. 468, d. 5938, Journals of the Conferences of Laybach (1821).

Io. In a note verbale inserted into the Laibach journals, France agreed to send to its representative in Naples the same instructions that the Austrian, Prussian, and Russian diplomats received. Britain, by contrast, denounced the revolution, but refused to abandon the policy of neutrality. AVP RI, f. 133, op. 468, d. 5938, 11. 365-65ob., journal of I3 January I822. On the expectation of political reform, see $V P R$, v. 3 (II), doc. 207 (30 December I820/II January I82I), pp. 684-89, report from Kapodistrias to Alexander; doc. 208 (3I December 1820/I2 January I82I), pp. 689-91, promemoria of Kapodistrias's conversation with plenipotentiary of the Kingdom of the Two Sicilies Ruffo; doc. 209 (2/14 January I82I), pp. 692-94, memorandum of Russia's plenipotentiaries; doc. 210 (6/18 January I82I), pp. 695-70I, Italinskii to Kapodistrias. On the allies' posture toward King Ferdinand I, see $V P R$, v. 3 (II), doc. 214 (I7/29 January I82I), pp. 707-8, memorandum of Russia's plenipotentiaries.

II. The response of the allies was certified on 25 January. AVP RI, f. I33, op. 468 , d. 5938, 11. 5-90b., 355-56ob., journals of 30 December 1820 and 31 December 1820/12 January I821.

I2. Roberts, "Italy," 43I-33; Stites, Four Horsemen, location 3876-4004. The allies assumed that the Neapolitan people supported their king and believed they were obeying his wishes when they accepted the revolution. VPR, v. 3 (II), doc. 204 (I5/27 December 1820), pp. 677-80, circular dispatch from Kapodistrias to envoys in the states of the German Confederation, the Netherlands, Switzerland, Denmark, and the Swedish-Norwegian kingdom.

I3. Martsio Mastrilli, Duke of Gallo (1753-1833).

I4. The papal plenipotentiary, Cardinal Spina, did not possess the authority to share the pontiff's views with the allies. The cardinal did note, however, that despite the pope's 
neutrality, he wished to see the restoration of order in Naples. AVP RI, f. 133, op. 468, d. 5938 , 11. 25-26ob., journal of I/I3 January I82I; $11.32-380$ ob., journal of 4/I6 January I82I; 11. $52-58$, journal of $7 / 19$ January I82 I; 11. 63-64, journal of 9/2I January I82 I; 11. 77-78, journal of $13 / 25$ January I82 I; 11. 84-94, journal of I $4 / 26$ January I 821, 1l. 99-100, journal of I6/28 January i821; 11. 356-68ob., journal of 31 December 1820/12 January i821. See also Stites, Four Horsemen, location 3876-4004.

I5. On the instructions and dispatches read at the conference and on concerns about the safety of the royal family in Naples, see AVP RI, f. I33, op. 468, d. 5938, 11. 99-100, 368-68ob., journal of I6/28 January I 821 .

16. The Duke of Gallo reported that he would return to Naples with the letter from Ferdinand to the Duke of Calabria and that he would request additional orders from the king. AVP RI, f. I33, op. 468, d. 5938, 11. 135-36ob., journal of I8 January I821; 11. I37$38 \mathrm{ob}$., allocution of Metternich to Gallo (I8/30 January I82I); 1l. 380-85ob., dispatch to Stackelberg (19/3I January I82I); 11. 386-88, dispatch to Stackelberg (19/3I January I82I); 11. $389-89 \mathrm{ob}$., journal of I 8 January I $82 \mathrm{I}$.

17. AV PRI, f. 133, op. 468, d. 5938, ll. 117-22, rescript to Stackelberg (9/21 November 1820 ).

18. Stackelberg, Alexander's envoy in Vienna from I818 to 1835, served in Naples in $1820-22$.

19. AVP RI, f. 133, op. 468, d. 5938, ll. 117-22, rescript to Stackelberg (9/21 November I 820$)$.

20. AVP RI, f. I33, op. 468, d. 5938, 11. IOI-8, copy of the Austrian instruction sent to Stackelberg; 1l. 369-79, instruction for Austria's ministers and chargés d'affaires (19/3I January I $82 \mathrm{I}$ ).

2I. If the disorders ended spontaneously, no war contribution would be levied on the peoples of the Two Sicilies. If military force had to be used and war broke out, a war levy would be imposed. AVP RI, f. 133, op. 468, d. 5938, ll. III-I6, draft dispatch to Stackelberg (19/3I January I82I); 11. I23-250b., dispatch to Stackelberg (19/3I January I82I); 11. 380-85ob., dispatch to Stackelberg (19/3I January I82I); 11. 386-88, dispatch to Stackelberg (19/3I January I82I).

22. AVP RI, f. 133, op. 468, d. 5938, ll. II I-16, draft dispatch to Stackelberg (19/31 January I82I); 11. 380-85ob., dispatch to Stackelberg (I9/3I January I82I).

23. AVP RI, f. I33, op. 468, d. 5938, 11. I44-46ob., Austria's position on the army of occupation (29 January I $82 \mathrm{I}$ ).

24. The conference journal of $8 / 20$ February i82I recorded formal acceptance of the Austrian military plan by Modena, the Roman (papal) state, and Tuscany. AVP RI, f. I33, op. 468, d. 5938, 1l. I4I-430b., journal of 2I January/2 February I82I; 11. I49-50, Russia's opinion on Austria's proposals for the army of occupation (2I January/2 February I821); 11. 153-550b., journal containing the thoughts of the "King of Naples" on the principles of political reform (8/20 February I82I); 11. 390-9I, journal containing Metternich's presentation of Austria's plan for the army of occupation (2I January I82I); 1l. 392-920b., journal of 8 February I82I. 
25. According to Henry Kissinger, the plan for political reconstruction in the Two Sicilies came from Metternich. Henry A. Kissinger, $A$ World Restored: Metternich, Castlereagh, and the Problems of Peace, I8I2-I822 (Boston: Houghton Mifflin Company, 1957), 276-79.

26. AVP RI, f. I33, op. 468 , d. 5938 , ll. $153-550 b$., journal containing the thoughts of the "King of Naples" on the principles of political reform (8/20 February I82I); 11. 392-920b., journal of 8 February I82I.

27. AVP RI, f. I33, op. 468, d. 5938, 11. I6I-69ob., journal containing the responses of the courts of Italy to the principles proposed by the King of Naples (9/2I February I82I); 11. I71-720b., journal of Io/22 February I821; 11. 178-79, declaration of Russia's plenipotentiaries approved by the emperor in response to the proposals of Prince Ruffo ( 20 February) and the responses of the courts of Italy (IO/22 February I821); 1. 393, journal containing the responses of the courts of Italy to the principles proposed by the King of Naples (9 February I821); 1. 394, journal of Io February I821; VPR, v. 3 (II), annotation (Io/22 February I82I), p. 717, declaration of Russia's plenipotentiaries in response to the declarations of Prince Ruffo (20 February) and the plenipotentiaries of other Italian courts (2I February); annotation (I4/26 February I82I), p. 719, session protocol signed by the plenipotentiaries of Russia, Austria, Britain, Modena, the Kingdom of the Two Sicilies, the Roman (papal) state, Prussia, the Kingdom of Sardinia, Tuscany, and France. At the conferences in Verona in December 1822, the plenipotentiaries of Austria, Britain, France, Prussia, Russia, and the Kingdom of the Two Sicilies approved Ferdinand I's request for allied assistance in hiring Swiss mercenaries to serve in his kingdom. The plenipotentiaries of Austria, Prussia, Russia, and the Two Sicilies also supported Ferdinand I's appeal to Francis I to extend the period of the Austrian occupation, if the king considered this necessary. Nesselrode and Bernstorff accepted Metternich's determination that the occupation remained necessary. $V P R$, v. 4 (I2), annotation (8 December I822), p. 604, session protocol approved by the plenipotentiaries of Russia, Austria, Britain, Prussia, and the Kingdom of the Two Sicilies; annotation (9 December 1822), p. 605, confidential protocol of the meeting of the plenipotentiaries of Russia, Austria, Prussia, and the Kingdom of the Two Sicilies. The original occupation was regulated by the Convention of Naples (6/18 October I82I). VPR, v. 4 (I2), annotation (6/18 October I82I), p. 319, convention on the occupation of the Kingdom of the Two Sicilies by the Austrian army concluded between Russia, Austria, Prussia, and the Kingdom of the Two Sicilies.

28. AVP RI, f. I33, op. 468, d. 5938, 11. I83-84, journal of I4/26 February I821; 11. 395950b., journal of I 4 February I82I; $V P R$, v. 3 (II), annotation (I4/26 February I82I), p. 719, session protocol signed by the plenipotentiaries of Russia, Austria, Britain, Modena, the Kingdom of the Two Sicilies, the Roman (papal) state, Prussia, the Kingdom of Sardinia, Tuscany, and France.

29. For reports and bulletins on the military occupation, see AVP RI, f. 133, op. 468 , d. $5938,11.396-438$.

30. Stites, Four Horsemen, location 4200-4215; Schroeder, Transformation, 612-14; Kissinger, World Restored, 279-83. 
31. AVP RI, f. I33, op. 468, d. 5938, 11. 189-89ob., declaration of Austria, Russia, and Prussia on the decisions made in Laibach (I2 May I82I); VPR, v. 3 (II), n. 30I, pp. 808-IO. The declaration appeared in Conservateur Impartial, no. 39 (I82I), though the copy from the British Library that I consulted did not contain the relevant pages. Alexander left Laibach on I/13 May I82 I. For the text of the declaration, see F. F. Martens, Recueil des traités et conventions, conclus par la Russie avec les puissances étrangères, I5 vols. (Saint Petersburg: Tipografiia Ministerstva Putei Soobshcheniia, 1874-1909), v. 4, no. 123, pp. 287-92.

32. After I8Is Russia accepted the return to the Ottoman policy that in peacetime closed the straits to foreign warships. This protected the Black Sea coast from Britain and France. Russian-Ottoman treaties of 1799 and 1805 had allowed the Russian fleet to pass through the straits in wartime. Alexander Bitis, Russia and the Eastern Question: Army, Government, and Society, I815-1833 (Oxford: Oxford University Press for the British Academy, 2006), I-30; E. P. Kudriavtseva, Russkie na Bosfore: Rossiiskoe posol'stvo v Konstantinopole v pervoi polovine XIX veka (Moscow: Nauka, 2010), 197-215; Barbara Jelavich, Russia's Balkan Entanglements, I806-I9I4 (New York: Cambridge University Press, 1991), 6-7.

33. I. S. Dostian, "Venskii Kongress (1814-18I5) i vostochnyi vopros," in Balkanskie issledovaniia. Vypusk I8. Aleksandr I, Napoleon i Balkany, ed. V. N. Vinogradov (Moscow: Nauka, 1997), 248-59.

34. RGADA, f. I5, op. I, d. 279, Documents concerning diplomatic relations with European powers from the Ministry of Foreign Affairs (I8I 4-2I), 11. 99-IOIob., relations with Turkey and Persia; Dostian, "Venskii Kongress," 256-58. The Porte (or Sublime Porte) referred to the central government of the Ottoman Empire in Constantinople. The Porte included the sultan, Divan (supreme council of the Ottoman Empire, which advised the sultan and assisted in administration), grand vizier, and other significant ministers. See Theophilus C. Prousis, Lord Strangford at the Sublime Porte: The Eastern Crisis, Vol. I: 1821 (Istanbul: Isis Press, 2010), I3.

35. Baron Stroganov's negotiations were ongoing. VPR, v. 2 (Io), doc. 164 (3/15 November I818), pp. 567-69, Alexander to Mahmood II; doc. I83 (8/20 November I819), pp. 630-34, note from Stroganov to the Ottoman government.

36. The Vladimirescu revolt began in January 1821. Starting in the early eighteenth century, the sultan appointed Phanariot Greeks, aristocrats from the Phanar district of Constantinople, rather than local boyars, to serve as hospodars, or governors, in Moldavia and Wallachia. An imperial decree issued by Sultan Selim III in 1802 and the Treaty of Bucharest (I8I2) allowed Russia to approve these appointments. Revolt in the Morea began on 25 March (OS). Stites, Four Horsemen, chap. 4; Bitis, Russia and the Eastern Question, 98-115; Jelavich, Russia's Balkan Entanglements, 6-8; Prousis, Greek Revolution; Prousis, Lord Strangford (182I); Theophilus C. Prousis, Lord Strangford at the Sublime Porte: The Eastern Crisis, Vol. 2: 1822 (Istanbul: Isis Press, 2012); Victor Taki, "The Russian Protectorate in the Danubian Principalities: Legacies of the Eastern Question in Contemporary Russian-Romanian Relations," in Russian-Ottoman Borderlands: 
The Eastern Question Reconsidered, ed. Lucien J. Frary and Mara Kozelsky (Madison: University of Wisconsin Press, 2014), 35-72.

37. Attacks on the Orthodox religion violated the Treaty of Kuchuk Kainardji (1774), and starting in May, restrictions on commercial ships flying the Russian flag violated both the treaty of 1774 and the commercial treaty of 1783 . Finally, dismissal of the hospodars and tax levies in Moldavia and Wallachia also violated Russia's treaty rights. Bitis, Russia and the Eastern Question, 104-15; Jelavich, Russia's Balkan Entanglements, 2-5. On Alexander's conclusion that the Porte was waging war not against revolutionaries, but against the Greek population and Christian religion, see $V P R$, v. 4 (I2), doc. 43 (II/23 April I82I), pp. II8-I9, note from Stroganov to the Ottoman government; annotations (I6/28 June I82I), p. 178, Nesselrode to Stroganov. In April, Stroganov still could report progress in discussions about illegal taxation and free trade in the Danubian Principalities: $V P R$, v. 4 (I2), annotation (Io/22 April I82I), p. II2, Stroganov to Nesselrode.

38. On 24 February/8 March, Ypsilantis wrote to Alexander in Laibach to request retirement from Russian service and assistance for the Greek people. The monarch's reply of I $4 / 26$ March called the revolt a criminal act. The patriarch of Constantinople also pronounced an anathema on Ypsilantis, and at the end of March (OS), Nesselrode instructed military commanders in Bessarabia not to accept refugees from the principalities who sought Russian protection. Even so, Ypsilantis may have received support from future Decembrists serving in the Second Army. Among military officers and officials in the south, Alexander's support for Ypsilantis was assumed. In May, moreover, Russia refused to hand over Greek refugees to the Porte. $V P R$, v. 4 (I2), annotation (24 February/8 March I82I), p. 39, Ypsilantis to Alexander; annotations (I 4/26 March I82I), p. 68, Nesselrode to Stroganov, Kapodistrias to Ypsilantis, personal letter from Kapodistrias to R. Edling; Stites, Four Horsemen, location 4582-4850; Bitis, Russia and the Eastern Question, 98-II5. On Russia's role as protector of Balkan Christians and the privileges granted to Moldavia, Wallachia, and Serbia, see Jelavich, Russia's Balkan Entanglements, chap. I. According to Jelavich, there was never a consistent or recognized definition of what it meant to protect the Porte's Orthodox subjects. Russia, however, tended to view political conditions as part of religious protection. Jelavich, Russia's Balkan Entanglements, 32-4I.

39. A larger Greek crisis and much internal Greek strife continued after the London Protocol of 3 February 1830 established an independent kingdom. The Greek civil war ended in I834. Jelavich, Russia's Balkan Entanglements, 84-89; VPR, v. 4 (I2), annotation (22 May/3 June I82I), p. I59, note from Stroganov to the Ottoman government; annotation (I/I3 July I82I), p. 200, Lebzeltern to Metternich.

40. Bitis, Russia and the Eastern Question, 98-II5; Prousis, Greek Revolution; I. S. Dostian, Russkaia obshchestvennaia mysl' i balkanskie narody: Ot Radishcheva do dekabristov (Moscow: Nauka, 1980); Charles and Barbara Jelavich, The Establishment of the Balkan National States, 1804-1920 (Seattle: University of Washington Press, 1977); Jelavich, Russia's Balkan Entanglements; Misha Glenny, The Balkans: Nationalism, War, and the Great Powers 1804-201I (New York: Penguin Books, 2012), 16-19, 21-39; Schroeder, 
Transformation, chap. 13. For the text of the Russian ultimatum and the Porte's failure to respond, see $V P R$, v. 4 (12), annotation (16/28 June 182I), p. 178, Nesselrode to Stroganov; doc. 78 (6/18 July I82I), pp. 203-IO, note from Stroganov to the Ottoman government; annotation (14/26 July I82I), p. 224, note from Stroganov to the Ottoman government; doc. 83 (I5/27 July I82I), pp. 224-25, Stroganov to Nesselrode; doc. 84 (I7/29 July I82I), pp. 227-28, Nesselrode to Alopeus, chargé d'affaires in London P. A. Nikolai, and Pozzo di Borgo; AVP RI, f. I33, op. 468, d. I1853, Vienna and Verona (I822), t. 1, 1l. 348-510b., summary of note from Stroganov to the Porte (16/28 July I82I); letter from the Russian government to the grand vizier (13/25 September I82I); memorandum to Russia's representatives in Vienna, Berlin, Paris, and London to serve as an instruction ( $13 / 25$ September I82I); note from the British ambassador to Nesselrode (IO/22 May I822); response from Nesselrode to Chevalier Bagot (I3 May I822); rescript to Tatishchev of I 4 May I822 (14/26 May I822). In a letter of $13 / 25$ September I82I to the grand vizier of the Ottoman Porte, the Russian government affirmed the ultimatum of $6 / 18$ July and the actions taken by Baron Stroganov. VPR, v. 4 (I2), annotation (I3/25 September I82I), p. 289, memorandum of the Russian government to the grand vizier of the Ottoman Porte. On support for the Greek cause in Russian society, see also VPR, v. 4 (I2), annotation (24 July/s August I82I), p. 238, appeal of the minister of spiritual affairs and popular enlightenment A. N. Golitsyn to the population of Russia; doc. I4I (I6/28 December I82I), pp. 400-I, Nesselrode to the main commander of the southern provinces of Russia A. F. Langeron; doc. I45 (3I December I82I/I2 January I822), pp. 408-9, Langeron to Nesselrode.

4I. $V P R$, v. 4 (I2), annotation (II/23 July I82I), p. 215, Alexander to Francis I; annotations (29 August/ıo September I82I), p. 279, letter from Alexander to Castlereagh; circular dispatch from Nesselrode to Alopeus, Golovkin, Nikolai, and Pozzo di Borgo; doc. 100 (29 August/Io September I82I), pp. 279-8I, circular dispatch from Nesselrode to Alopeus, Golovkin, Nikolai, and Pozzo di Borgo; doc. 103 (3/15 September I821), pp. 283-86, envoy in Turin G. D. Mochenigo to Nesselrode; doc. 106 (13/25 September I82I), pp. 290-92, Nesselrode to Golovkin; annotation (13/25 September 1821), p. 292, Nesselrode to Golovkin; doc. 107 (13/25 September 182I), pp. 292-94, personal letter from Nesselrode to Metternich; annotation (26 September/8 October I82I), p. 310, Pozzo di Borgo to Nesselrode.

42. $V P R$, v. 4 (12), annotation (10 July 1821), p. 197, French ambassador in Saint Petersburg Pierre-Louis-August La Ferronnays (1777-1842) to French minister of foreign affairs Pasquier; annotation (3/15 July I82I), p. 200, Lebzeltern to Metternich; annotation (7/19 September I82I), p. 286, La Ferronnays to Pasquier; annotations (13/25 September I82I), pp. 289-90, memorandum from the Russian government to the grand vizier of the Ottoman Porte; Nesselrode to Golovkin; doc. I22 (2I October/2 November I82I), pp. 330-40, Lieven to Nesselrode.

43. VPR, v. 4 (I2), annotations (22 June/4 July I82I), pp. I9I-92, confidential circular dispatch from Nesselrode to Golovkin, Alopeus, Pozzo di Porgo, and Nikolai; Nesselrode to Golovkin; Nesselrode to Golovkin.

44. VPR, v. 4 (12), doc. 78 (6/18 July I82I), pp. 203-10, note from Stroganov to the Ottoman government. For a statement of Russia's position, including Alexander's expectations 
of the allies, see the communication from Nesselrode to the monarch's envoys in Berlin, London, and Paris: VPR, v. 4 (12), doc. 72 (22 June/4 July I821), pp. I89-91, Nesselrode to Alopeus, Nikolai, and Pozzo di Borgo. See also Alexander's letter to Austrian emperor Francis I, in which he compared the principles being applied in the Levant to those that had been successful in Italy. $V P R$, v. 4 (I2), annotation (II/23 July I82I), p. 215.

45. $V P R$, v. 4 (I2), doc. 78 (6/18 July I82I), pp. 203-10, note from Stroganov to the Ottoman government.

46. $V P R$, v. 4 (I2), doc. 78 (6/18 July I82I), pp. 203-10.

47. $V P R$, v. 4 (I2), doc. 78 (6/18 July I821), pp. 203-10.

48. $V P R$, v. 4 (I2), doc. 100 (29 August/Io September I82I), pp. 279-8I, circular dispatch from Nesselrode to Alopeus, Golovkin, Nikolai, and Pozzo di Borgo; annotation (7/19 October 1821), p. 320, Nesselrode to Lieven. Russia accepted allied participation in resolving the crisis but did not accept allied mediation between the empire and the Porte. According to Nesselrode, the allies recognized Russia's right to protect the Christian population of the Ottoman Empire, a claim that some sources dispute. As noted above, the right to protect Christians living under Ottoman suzerainty could be interpreted in myriad ways. Prousis, Lord Strangford, vols. I-2; VPR, v. 4 (I2), annotation (13/25 September I82I), pp. 289-90, Nesselrode to Golovkin; doc. 106 (13/25 September I821), pp. 290-92, Nesselrode to Golovkin.

49. In I82I Nikolai served as chargé d'affaires (poverennyi v delakh) in London. VPR, v. 4 (I2), doc. 73 (22 June/4 July I82I), pp. 192-96, personal letter from Kapodistrias to Nikolai.

50. Percy Smythe, Sixth Viscount Strangford (1780-1855).

5I. $V P R$, v. 4 (I2), doc. I22 (2I October/2 November I82I), pp. 330-40, Lieven to Nesselrode; n. I53, p. 666.

52. Count Christian Gunther Bernstorff (1769-1835) served as Prussia's minister of foreign affairs from I818 to I832. Before entering Prussian service, he was Denmark's ambassador in Berlin (1816-18).

53. $V P R$, v. 4 (I2), doc. I22 (2I October/2 November I82I), pp. 330-40, Lieven to Nesselrode.

54. VPR, v. 4 (I2), doc. IIs (2/I4 October I82I), pp. 310-I4, personal letter from Golovkin to Kapodistrias.

55. VPR, v. 4 (I2), doc. I22 (21 October/2 November I82I), pp. 330-40, Lieven to Nesselrode.

56. $V P R$, v. 4 (12), doc. I22, pp. $330-40$.

57. VPR, v. 4 (I2), doc. 132 (27 November/9 December I82I), pp. 369-7I, Nesselrode to Lieven.

58. $V P R$, v. 4 (12), doc. 133 (27 November/9 December I821), pp. 37I-79, personal letter from Kapodistrias to Lieven.

59. $V P R$, v. 4 (12), doc. 134 (27 November/9 December I82I), pp. 379-82, Lieven to Nesselrode; doc. 136 (27 November/9 December 182I), pp. 384-86, Lieven to Nesselrode. 6o. VPR, v. 4 (I2), doc. 136 (27 November/9 December I82I), pp. 384-86, Lieven to Nesselrode. 
6I. $V P R$, v. 4 (I2), doc. I 40 (16/28 December I821), pp. 396-400, Golovkin to Nesselrode; doc. 148 (20 January/I February I822), pp. 4II-I4, Golovkin to Nesselrode.

62. Prousis, Greek Revolution, I8-24. In I818 Philiki Etaireia (Friendly Society), the nationalist society working to create an independent Greek state, moved its headquarters from Odessa to Constantinople. Lucien J. Frary, "The Russian Consulate in the Morea and the Outbreak of the Greek Revolution, I816-2I," in Diplomacy and Intelligence in the Nineteenth-Century Mediterranean World, ed. Mika Suonpää and Owain Wright (London: Bloomsbury Academic Publishing, 2019), 57-77. Since June I821, the Austrian government had promoted the idea that Greek rebels in Moldavia and Wallachia maintained ties to revolutionaries and Freemasons in other parts of Europe. Police reports from Vienna also tried to connect Kapodistrias to individuals suspected of involvement in the Greek rebellions. AVP RI, f. 133, op. 468, d. 2993, Doklady, 11. I-5, Nesselrode to Alexander (II June I82I); 11. 5-70b., translation of police report from Vienna (5 May I82I); 11. 8-Ioob., interrogation of Colonel Lisgara in Vienna (4-5 May I82I); 11. II-I3, interrogation of Antoine Zuni in Vienna (4 May I82I).

63. $V P R$, v. 4 (I2), doc. I52 (3I January/I2 February I822), pp. 421-26, Nesselrode to Golovkin.

64. Frary, "Russian Consulate," 57-77.

65. VPR, v. 4 (I2), annotations (27 November/9 December I821), p. 369 , Nesselrode to Lieven, Nesselrode to Golovkin, Nesselrode to Lieven; doc. 150 (25 January/6 February I822), pp. 418-19, Alexander to Metternich; annotation (3I January/I2 February I822), p. 42I, Nesselrode to Golovkin; doc. I52 (3I January/I2 February I822), pp. 42I-26, Nesselrode to Golovkin. Ongoing conversations between Golovkin and Metternich in Vienna did not produce satisfactory results. $V P R$, v. 4 (I2), doc. I40 (I6/28 December I82I), pp. 396-400, Golovkin to Nesselrode; doc. I 48 (20 January/i February I822), pp. 4II-I4, Golovkin to Nesselrode.

66. VPR, v. 4 (12), doc. 153 (5/17 February I822), pp. 426-30, rescript from Alexander to Tatishchev.

67. Alexander's policy, according to the rescript, had been developed over the past nine months in communications between his government and the allies; in a personal letter of 17/29 July 182I addressed to Austrian emperor Francis I; and in another letter to British foreign secretary Castlereagh, dated 29 August/Io September I821. See $V P R$, v. 4 (I2), annotation (II/23 July I82I), p. 215; annotations (29 August/Io September I82I), p. 279.

68. The Austrian proposals were summarized in a memorandum sent to Alexander's representatives at the courts of Berlin, London, Paris, and Vienna. See VPR, v. 4 (I2), doc. 154 (6/18 February 1822), pp. 430-43.

69. The term "Levant" referred to the islands and coastal areas of the eastern Mediterranean ruled by the Ottomans. See Prousis, Lord Strangford (I82I), I3. Although historians of Europe tend to use the term "Eastern Question," the documents of the era referred to "the crisis in the East."

70. At this time, all the diplomatic principals among the allies believed in the existence of a revolutionary directorate operating from Paris that sought to foment rebellion 
across Europe. $V P R$, v. 4 (I2), annotation (I3/25 September I82I), pp. 289-90, Nesselrode to Golovkin.

71. $V P R$, v. 4 (I2), doc. I54 (6/18 Februaryi 822), pp. 430-43, instruction from the Ministry of Foreign Affairs to Golovkin, Alopeus, Lieven, and Pozzo di Borgo; doc. 155 (8/20 February 1822), pp. 443-45, Nesselrode to Alopeus, Lieven, and Pozzo di Borgo; annotation (27 February/II March 1822), p. 447, personal letter from Tatishchev to Nesselrode. Metternich and Castlereagh met in Hanover in October I82I to discuss the crisis, and in December, Austria communicated to Russia proposals for modification of the ultimatum. On the Hanover meetings, see Lieven's report to Nesselrode in $V P R$, v. 4 (I2), doc. I22 (2I October/2 November I82I), pp. 330-40. According to Jelavich, Austria and Britain assumed that Russia sought domination in the East and therefore agreed to refuse or block Alexander's requests for allied cooperation. Jelavich, Russia's Balkan Entanglements, 52-75.

72. Alexander also agreed to accept a statement of Ottoman intentions regarding the first three points along with proof of action on the fourth. Previously, the emperor had demanded proof of action on all four points. AVP RI, f. I33, op. 468, d. II853, t. 1, 11 . 348 -5Iob., summary of note from Stroganov to the Porte (I6/28 July I82I); letter from the Russian government to the grand vizier (13/25 September I82I); memorandum to Russia's representatives in Vienna, Berlin, Paris, and London to serve as an instruction (I3/25 September I82I); note from the British ambassador to Nesselrode (IO/22 May I822); response from Nesselrode to Chevalier Bagot (I3 May I822); rescript to Tatishchev of 14 May I822 (I4/26 May I822).

73. VPR, v. 4 (I2), annotation (26 September/8 October I82I), p. 310 , Pozzo di Borgo to Nesselrode; doc. 154 (6/18 February 1822), pp. 430-43, instruction from the Ministry of Foreign Affairs to Golovkin, Alopeus, Lieven, and Pozzo di Borgo; doc. 157 (28 February/12 March I822), pp. 447-53, Tatishchev to Nesselrode; annotation (2/14 March I822), p. 454, verbal note from Tatishchev to Metternich; doc. I59 (IO/22 March I822), pp. 45457, Tatishchev to Nesselrode; doc. 164 (28 March/9 April I822), pp. 470-7I, Tatishchev to Alexander; doc. 165 (3/15 April 1822), pp. 471-74, Nesselrode to Tatishchev; doc. 166 (3/15 April I822), pp. 474-75, Nesselrode to Tatishchev, Lieven, and Pozzo di Borgo.

74. $V P R$, v. 4 (I2), doc. 154 (6/18 Februaryi 822), pp. 430-43, instruction from the Ministry of Foreign Affairs to Golovkin, Alopeus, Lieven, and Pozzo di Borgo.

75. $V P R$, v. 4 (I2), doc. I7I (19 April/I May I822), pp. 482-96, Lieven to Nesselrode.

76. To break diplomatic relations implied that war was in the offing.

77. $V P R$, v. 4 (12), n. 233-36, p. 702.

78. Russia proposed the city of Kamenets-Podolsk in Ukraine as the site for the meeting. $V P R$, v. 4 (I2), doc. 174 (13/25 May I822), pp. 506-7, letter from Nesselrode to Britain's ambassador in Saint Petersburg Bagot; AVP RI, f. 133, op. 468, d. I1853, t. 1, 11. 348-51ob., note from Stroganov to the Porte (16/28 July I82I); letter from the Russian government to the grand vizier ( $13 / 25$ September I82I); memorandum to Russia's representatives in Vienna, Berlin, Paris, and London to serve as an instruction (13/25 September I82I); note from the British ambassador to Nesselrode (10/22 May 1822); response from Nesselrode to Chevalier Bagot (13 May I822); rescript to Tatishchev of I4 May I822 (I4/26 May I822). 
79. $V P R$, v. 4 (I2), doc. 175 (I4/26 May I822), pp. 507-13, rescript from Alexander to Tatishchev; doc. 176 (16/28 May I822), p. 513, Nesselrode to Tatishchev; doc. 178 (17/29 May I822), p. 515, Nesselrode to Pozzo di Borgo; doc. I82 (9/21 June I822), pp. 526-29, Tatishchev to Alexander; annotation (28 June 1822), p. 536, session journal from the Vienna conference of the plenipotentiaries of Russia, Austria, Britain, and France; annotation (27 July 1822), p. 547, session journal from the Vienna conference of the plenipotentiaries of Russia, Austria, Britain, Prussia, and France. Although Alexander preferred to see the return of hospodar rule, based on the regulations stipulated in previous treaties, he also expressed a willingness to entertain changes in the organization of local government. $V P R$, v. 4 (12), annotation (13/25 September I821), pp. 289-90, Nesselrode to Golovkin; annotation (24 February/8 March 1822), p. 446, verbal note from Tatishchev to Metternich.

80. AVP RI, f. 133, op. 468, d. I1853, t. 1,11.348-51ob., note from Stroganov to the Porte (I6/28 July I82I), letter from the Russian government to the grand vizier ( $13 / 25$ September I821); $V P R$, v. 4 (I2), doc. I89 (13/25 July I822), pp. 543-46, Nesselrode to Tatishchev.

8I. RGADA, f. 3, op. I, d. 82, Papers of Kapodistrias (I822), plan for military action against Turkey presented by Colonel Buturlin; Bitis, Russia and the Eastern Question, $149-60$.

82. By the end of the year a new ecumenical patriarch had been selected, but the Porte still had not consulted with Russia about the appointment of the hospodars. Prousis, Lord Strangford (I822), II-I2.

83. The Porte interpreted the sending of envoys as acceptance of allied intervention in the Ottoman Empire's internal administration, in this case, represented by the pacification of Greece. AVP RI, f. 133, op. 468, d. 11853, t. 1, 11. 352-75, summary of the conference of 27 August 1822 with the reis effendi in Constantinople.

84. AVP RI, f. I33, op. 468, d. I1853, t. 1, 11. 348-51ob., memorandum to Russia's representatives in Vienna, Berlin, Paris, and London to serve as an instruction ( $13 / 25$ September I82I); note from the British ambassador to Nesselrode (Io/22 May I822); response from Nesselrode to Chevalier Bagot (I3 May I822); rescript to Tatishchev of I 4 May I 822 (I4/26 May i822).

85. The conferences in Verona focused on Spain, but also addressed the situation in Italy and the crisis in the East. The full record is preserved in two volumes as AVP RI, f. 133 , op. 468 , d. I1853. In May I822, after opposing the decision to address the Greek question at allied conferences scheduled for September, Kapodistrias went on indefinite leave from Russian service. In general, Kapodistrias supported the independence of Greece and the use of Russian military force on behalf of the Greeks. He also opposed European involvement in Russian-Ottoman conflicts. Because of Castlereagh's suicide on 12 August, the allied conferences were delayed. Bitis, Russia and the Eastern Question, II2-15; Ocherki istorii Ministerstva inostrannykh del Rossii. 1802-2002. Vol. 3: Biografii ministrov inostrannykh del. 1802-2002 (Moscow: Olma-Press, 2002), 88-99.

86. AVP RI, f. 133, op. 468, d. I1 853, t. 1, 11.376-78ob., Russian statement approved by Alexander (9/2I September 1822). 
87. Although by September i822 most Ottoman troops had left, the last units remained until 1826 .

88. Reports of restrictions on Russian commercial shipping began to appear in May I82I. $V P R$, v. 4 (I2), doc. 58 (4/16 May I82I), pp. I54-55, note from Stroganov to the Ottoman government; annotation (I2/24 May I82I), p. I56, note from Stroganov to the Ottoman government; doc. 6I (17/29 May I82I), pp. 158-59, circular dispatch from Stroganov to Russia's consular representatives in Alexandria, Aleppo, Athens, Dardanelles, Patras, Salonica, Saint Jean d'Acre (Akko), Skalanova (Izmir), Sinop, Smyrna, Enos, Jaffa, and on the islands Keia, Kipr, Mitilini, Naksos, Rodos, Samos, Santorini, Tinos, Khios.

89. AVP RI, f. I33, op. 468, d. I1853, t. 1, 11. 379-85ob., Russian note to the plenipotentiaries of Austria, France, Britain, and Prussia (14/26 September 1822); VPR, v. 4 (I2), doc. 202 (I $4 / 26$ September I822), pp. 58I-85, note from Nesselrode to Metternich, Montmorency, Wellington, and Bernstorff.

90. AVP RI, f. 133, op. 468, d. 11853, t. 1, 1l. 379-85ob., Russian note to the plenipotentiaries of Austria, France, Britain, and Prussia (I4/26 September I822); t. 1, 11. 424-28, Russia's declaration on the "Affairs of the East" (9 November I822).

91. AVP RI, f. 133, op. 468, d. I1853, t. 1, 11. 424-550b., Russia's declaration on the "Affairs of the East" (9 November I822); VPR, v. 4 (I2), annotation $(28$ October/9 November I822), p. 589 , declaration of Tatishchev.

92. AVP RI, f. I33, op. 468, d. 11853, t. 1, 11. 436-550b., responses of Austria, France, Prussia, and Britain to Russia's declaration of 9 November; Alexander's response to the allies' responses; insertion of the declaration into the protocol of the conference ( $16 / 28$ November 1822). According to Bitis, in 1822 Austria and Britain worked to prevent Russian action. To that end, Metternich manipulated Alexander to allow time for the Ottomans to suppress the revolt, and during three years of conferences, Austria and Britain blocked Russian efforts to conclude an allied agreement on action in Greece. Bitis, Russia and the Eastern Question, II2-15, 16I-67.

93. AVP RI, f. I33, op. 468, d. II 853 , t. 1, 11. 440-44, 450-55, discussion of Russia's declaration (26-27 November 1822).

94. AVP RI, f. I33, op. 468, d. II853, t. 1, 11. 47-48ob., conferences of I8, 19, 20 November 1822 .

95. The impact of public opinion is also relevant but must be studied in local/national context.

96. In instructions to diplomatic appointees, Alexander repeatedly stated his commitment to allied unity. See, for example, VPR, v. 4 (I2), doc. 172 (27 April/9 May I822), pp. 496-500, rescript from Alexander to Ivan Illarionovich Vorontsov-Dashkov (1790-1854).

97. From March 1823 Britain recognized the Greeks as legal belligerents entitled in wartime to the same rights as sovereign states, though without acknowledging Greek sovereignty.

98. Will Smiley, "War without War: The Battle of Navarino, the Ottoman Empire, and the Pacific Blockade," Journal of the History of International Law i8 (2016): 42-69; Schroeder, Transformation, chap. I4; Jelavich, Balkan National States, 38-52; 
Jelavich, Russia's Balkan Entanglements, 65-89; Bitis, Russia and the Eastern Question, 161-76, 426-29; Glenny, The Balkans, 30-39; Prousis, Greek Revolution, 52-54; Prousis, Lord Strangford (1822), 356; Kissinger, World Restored, 260-97; Patricia Grimsted, The Foreign Ministers of Alexander I: Political Attitudes and the Conduct of Russian Diplomacy, I80I-I825 (Berkeley: University of California Press, 1969), 259-63; Jennifer Mitzen, Power in Concert: The Nineteenth-Century Origins of Global Governance (Chicago: University of Chicago Press, 2013), 102-41; O. V. Orlik, Rossiia v mezhdunarodnykh otnosheniiakh I8I5-I829: Ot Venskogo kongressa do Adrianopol'skogo mira (Moscow: Nauka, 1998), 40-48. See also VPR, v. 4 (I2), doc. 175 (14/26 May 1822), pp. 507-13, rescript from Alexander to Tatishchev; doc. 176 (16/28 May 1822), p. 513, Nesselrode to Tatishchev; doc. I82 (9/2I June I822), pp. 526-29, Tatishchev to Alexander; annotation (28 June $1822 \mathrm{NS}$ ), p. 536 , session journal signed by the plenipotentiaries of Russia, Austria, Britain, and France at the Vienna conference convened at Russia's request; doc. 189 (13/25 July 1822), pp. 543-46, Nesselrode to Tatishchev; annotation (13/25 November 1822), p. 593, Nesselrode to Metternich; annotation (I5/27 November 1822), p. 599, declaration of Tatishchev. In April 1827 Kapodistrias was elected president by the national assembly of Greece in Trizin, in July he formally retired from Russian service, and on 27 September 1831, he was assassinated. Ocherki, v. 3, pp. $88-99$.

99. Ironically, Alexander's insistence that news of military and popular uprisings not be published in the Vedomosti and that the Russian press not be allowed to discuss official policy on the Eastern Question also highlighted his moderation. VPR, v. 4 (12), doc. 9 (I/13 March 1821), p. 47, Interim Minister of Foreign Affairs P. G. Divov to Golitsyn; annotation (13/25 September 182I), p. 292, Nesselrode to Golovkin. On Alexander's orders to constrain Stroganov, see VPR, v. 4 (I2), annotation (I2/24 September 182I), p. 288, Alexander to Nesselrode. On the rift with Kapodistrias, long encouraged by Metternich, see $V P R$, v. 4 (I2), annotation (28 December I82I/9 January I822), p. 405, Lebzeltern to Metternich; doc. 143 (29 December 1821/10 January 1822), pp. 405-6, Alexander to Metternich; annotations (29 December I821/10 January 1822), p. 406, letter from Kapodistrias to Nesselrode, letter from Nesselrode to Kapodistrias; annotation (31 December 1821/12 January I822), p. 406, letter from Kapodistrias to Alexander; annotation (not before 31 December 1821/12 January 1822), p. 406, letter from Alexander to Kapodistrias; doc. 179 (17/29 May 1822), pp. $515-16$, personal letter from Kapodistrias to Lieven. For Kapodistrias's views on the crisis, see VPR, v. 4 (I2), doc. 73 (22 June/4 July I82I), pp. 192-96, personal letter from Kapodistrias to Nikolai; doc. 95 (9/21 August 182I), pp. 256-65, memorandum from Kapodistrias to Alexander; doc. I2I (II/23 October I82I), pp. 327-30, memorandum of Kapodistrias; doc. $173(\mathrm{I} / \mathrm{I} 3$ May 1822), pp. 500-506, report from Kapodistrias to Alexander.

Ioo. David A. Bell, The First Total War: Napoleon's Europe and the Birth of Warfare as We Know It (New York: Houghton Mifflin Harcourt, 2007). 


\section{Chapter 5: Spain and the European System (1820-23)}

I. Spain's accession resulted from the Treaty of Paris of ıo June I817. AVP RI, f. I33, op. 468, d. 2992, Doklady, 11. 204-4ob.

2. RGADA, f. I5, op. I, d. 279, Documents concerning relations with European powers from the Ministry of Foreign Affairs, 11. 74-76ob., appendix to the overview of 5/17 June I8I7 on the accession of Spain to the acts of the Congress of Vienna; M. A. Dodolev, Rossiia i Ispaniia, I808-1823: voina i revoliutsiia v Ispanii i russko-ispanskie otnosheniia (Moscow: Nauka, 1984), i16-23.

3. RGADA, f. I5, op. I, d. 279, 11. 88-90ob., appendix to the overview of 5/17 June 1817 on the political system in Spain.

4. On the sale of the warships, see $V P R$, v. I (9), doc. 190 (30 July/II August I8I7), pp. 626-30, act on the sale of warships to Spain by Russia; v. 2 (Iо), doc. 8 (17/29 October 1817), pp. 24-27, Nesselrode to Tatishchev; doc. Io (26 October/7 November 1817), pp. 30-35, Lieven to Nesselrode; v. 3 (II), doc. 39 (I5/27 September I8I9), pp. II8-2I, supplemental convention between Russia and Spain to the act on the sale of warships to Spain by Russia; doc. 63 (26 November/8 December 1819), pp. 184-85, Nesselrode to Tatishchev; doc. 135 (Io/22 June I820), pp. 424-25, Nesselrode to Pozzo di Borgo; Dodolev, Rossiia i Ispaniia, I28-35.

5. Russia's envoy in Rio de Janeiro also received instructions to encourage Portuguese Brazil to cooperate with the European powers to end the slave trade. $V P R$, v. 2 (Io), doc. I70 (9/2I November I8I8), p. 583, Alexander to Ferdinand VII; doc. I72 (9/2I November I8I8), pp. 585-88, instruction from Nesselrode to envoy in Rio de Janeiro F. V. Teil'-fanSeroskerken (Theodor Tuyll van Seroskerken). By April I8I8, British foreign secretary Castlereagh had concluded treaties on the slave trade with Portugal, Spain, and the Netherlands. Portugal agreed to abolish the trade, except along the African coast south of the equator. Spain agreed to abolition north of the equator and everywhere else after May 1820. In addition, both Portugal and Spain received 700,000 pounds in compensation. The Netherlands accepted complete abolition without compensation. John Bew, Castlereagh: A Life (New York: Oxford University Press, 2012), 446-47.

6. RGADA, f. 3, op. I, d. 162, Précis of the work of the conferences of Aix-la-Chapelle (I818), 11. II-I2, sessions of 23,24 October on the Spanish colonies and abolition of the slave trade; 11. 16-17ob., session of 4 November on abolition of the slave trade; 11. 18ob.2I, session of 7 November, memorandum from the Russian government on the measures proposed by Britain to ensure abolition of the slave trade; 11. 33ob.-36ob., session of II November on the French, Austrian, and Prussian responses to Britain's proposals concerning abolition of the slave trade, and on threats to trade and navigation from piracy.

7. The Spanish viceroyalty of Rio de la Plata (present-day Argentina, Bolivia, Paraguay, and Uruguay) began to break up and proclaim independence in I810. Montevideo remained loyal to the Spanish regency; however, in addition to combating independence movements, Spain competed with Portuguese Brazil for the territory north of the Rio de la Plata. Brazil became independent of Portugal in I822-23. R. A. Humphreys, "The Emancipation of Latin America," in The New Cambridge Modern History. Vol. g: War 
and Peace in an Age of Upheaval, $1793-1830$, ed. C. W. Crawley (Cambridge: Cambridge University Press, 1965), 618-21, 630-32.

8. RGADA, f. I5, op. I, d. 279, ll. I02-103ob., appendix to the overview of $5 / 17$ June I8I 7 on disputes between Spain and Portugal. Russia initially pushed for allied intervention, if Portuguese Brazil did not rectify the aggression against Spain. Austria, Britain, and Prussia rejected the possibility of military action. Nor did the Spanish monarchy seek such assistance. Russell H. Bartley, Imperial Russia and the Struggle for Latin American Independence, $1808-1828$ (Austin: University of Texas Press, 1978), Kindle edition, location 2363-2495.

9. RGADA, f. 3, op. I, d. 162, 11.7ob.-8ob., sessions of 15,17 October on the question of Spain; 11. 78-79, session of 22 November on the question of Spain.

Io. $V P R$, v. 3 (II), doc. 75 (not later than 3i December I8I9/12 January I820), pp. 215-18, Tatishchev to Ferdinand VII.

II. One recent popular biography identifies Alexander as a "sovereign" or "autocratic republican.” Leonid Mikhailovich Liashenko, Aleksandr I. Samoderzhavnyi respublikanets (Moscow: Molodaia gvardiia, 20r4). For illuminating and balanced discussion of Alexander's domestic policies and understanding of constitutions, see Patrick O'Meara, The Russian Nobility in the Age of Alexander I (London: Bloomsbury Academic, 2019), chap. 8.

I2. $V P R$, v. 3 (II), doc. 83 (I5/27 January I820), pp. 232-34, Bulgari to Nesselrode.

13. Ferdinand VII returned to power in I8I 4. $V P R$, v. 3 (II), doc. 99 (24 February/7 March I820), pp. 300-6, Bulgari to Nesselrode; doc. I00 (24 February/7 March I820), pp. 306-I2, Bulgari to Nesselrode.

I4. $V P R$, v. 3 (II), doc. IOI (24 February/7 March I820), pp. 312-I4, Bulgari to Nesselrode. On I9 April/s May I820, Nesselrode conveyed a reprimand from Alexander to Count Bulgari, who had exceeded his authority and instructions by trying to counsel Ferdinand VII on how to respond to the revolutionary crisis. See $V P R$, v. 3 (II), doc. IIs (ı April/r May 1820), pp. 356-57, Nesselrode to Bulgari. Russian diplomatic documents repeatedly referred to the revolution of 8 March; however, historians identify 7 March as the day that Ferdinand accepted the constitution, after summoning the Cortes. On 8 March the king ordered the release of political prisoners, and on 9 March, celebrated as the day of the revolution, he took the oath to the I8I2 constitution. Richard Stites, The Four Horsemen: Riding to Liberty in Post-Napoleonic Europe (New York: Oxford University Press, 2014), Kindle edition, location 1485-1638; Dodolev, Rossiia i Ispaniia, 166-68. Reports that reached Saint Petersburg in March described support for the Spanish insurrection in the provinces and the capital, King Ferdinand's acceptance of the $18 \mathrm{I} 2$ constitution, the failure of allied mediation in the dispute over the Rio de la Plata, and the encouragement to Spanish American insurgents provided by the revolution in Spain. AVP RI, f. 133, op. 468, d. 2992, Doklady, 1l. 3-4, summary of reports received from Russia's missions abroad from the end of the last year to the present day (30 March/I I April I820); VPR, v. 3 (II), doc. Io8 (30 March/ı April ı820), pp. 337-43, memorandum from Kapodistrias to Alexander.

I5. AVP RI, f. I33, op. 468, d. 2992, Doklady, 1l. I2-I 4ob., agenda of 6 April I820. 
I6. VPR, v. 3 (II), doc. 102 (3/15 March I820), pp. 315-18, Nesselrode to Lieven. The same communication was sent to minister plenipotentiary in Paris Pozzo di Borgo, envoy in Berlin Alopeus, envoy in Vienna Golovkin, envoy in Constantinople Stroganov, general consul in Bucharest Pini, governor-general of the Kingdom of Poland Grand Duke Constantine Pavlovich, envoy in Copenhagen Nikolai, and commander-in-chief of troops in Georgia General Aleksei Petrovich Ermolov.

17. $V P R$, v. 3 (II), doc. III (I3/25 April I820), pp. 348-50, Golovkin to Nesselrode.

I8. This communication also was sent to Pozzo di Borgo, Stroganov, Pini, Constantine Pavlovich, and Ermolov. VPR, v. 3 (II), doc. II3 (I9 April/ı May I820), pp. 351-53, Nesselrode to Golovkin, Lieven, and Alopeus. By the end of March, the Russian government sensed opposition to active intervention in Spain from Austria and Britain. AVP RI, f. I33, op. 468, d. 2992, Doklady, 1l. 3-4, summary of reports received from Russia's missions abroad from the end of the last year to the present day (30 March/I A April I820); $V P R$, v. 3 (II), doc. 108 (30 March/II April I820), pp. 337-43, memorandum from Kapodistrias to Alexander.

19. $V P R$, v. 3 (II), doc. II4 (I9 April/I May I820), pp. 354-56, Nesselrode to Pozzo di Borgo.

20. $V P R$, v. 3 (i ), annotation (is April/s May I820), p. 357, memorial memorandum from the Russian cabinet to Austria, Britain, Prussia, and France; annotation (20 April/2 May I820), p. 357, note from Nesselrode informing Cea Bermúdez, Spain’s chargé d'affaires in Saint Petersburg, that the allies would respond collectively to the Spanish government.

2I. VPR, v. 3 (II), doc. II9 (4/I6 May I820), pp. 374-8I, Lieven to Nesselrode; AVP RI, f. 133, op. 468, d. 2992, Doklady, 1l. 339-4I, report from Nesselrode to Alexander (24 August I820); Bew, Castlereagh, chap. I4.

22. In a state paper of 5 May 1820 , Castlereagh argued that a joint intervention in Spain would violate the treaties and purposes of the alliance. Paul W. Schroeder, The Transformation of European Politics $1763-1848$ (New York: Oxford University Press, 1994), 607-8; Jennifer Mitzen, Power in Concert: The Nineteenth-Century Origins of Global Governance (Chicago: University of Chicago Press, 2013), 106-10.

23. RGADA, f. I5, op. I, d. 279, 11. I86-88ob., note from Cea Bermúdez to Nesselrode (7/19 April I820).

24. Spanish resistance to Napoleonic rule began after Joseph Bonaparte became king (April I808) and imposed the Bayonne constitution. In September I808 the Supreme Central Junta, established in the town of Aranjuez, assumed leadership of the resistance, and the Cortes elected in I8Io, which met in León and then Cadiz, called for the return of Ferdinand VII as a constitutional monarch. (In March I808, Ferdinand had supported the forced abdication of Charles IV and had hoped to rule as Napoleon's protégé.) The 1812 constitution gave the king suspensive veto power over legislation but did not allow him to override or dissolve the Cortes. The king's power to cede territory or conclude aggressive alliances also was strictly limited. Finally, if the king left the country without permission, he abdicated the throne. The work of liberal politicians, the constitution also established a free press, equality before the law, the inviolability 
of the individual, and an independent judiciary. The king appointed cabinet ministers, who were responsible to the Cortes, and a state council, chosen by the king and Cortes, monitored the monarch's actions. After Ferdinand returned to power in March I8I 4 , he quickly abolished the Cortes and its ministries, restored censorship, purged the military, and ordered the arrest, imprisonment, and exile of liberal leaders. Stites, Four Horsemen, location 683-1329; Raymond Carr, "Spain and Portugal, I793 to c. 1840," in The New Cambridge Modern History. Vol. 9: War and Peace in an Age of Upheaval, 1793-1830, ed. C. W. Crawley (Cambridge: Cambridge University Press, 1965), 443-47.

25. RGADA, f. 15, op. I, d. 279, 11. 189-920b., note from Nesselrode to Cea Bermúdez (I8 April I820). Documents in the archive of the Russian Ministry of Foreign Affairs, including a report of 24 August 1820 from Nesselrode to Alexander, date the note to 20 April/2 May i820. In the August report, prompted by the Spanish government's complaint about the note's publication in the Saint Petersburg press, Nesselrode praised the "noble and conservative language" of the document, as well as the "pure" perspective contained therein. According to the co-minister of foreign affairs, it had been necessary to inform the Russian public about the note, which already had been publicized throughout Europe. Nesselrode described the note as potentially decisive for the peace of Europe and as a statement that reflected well on Russia. The use and manipulation of the press in the conduct of diplomacy is another topic in need of comprehensive research. AVP RI, f. 133, op. 468, d. 2992, Doklady, 11. 352-530b., report from Nesselrode to Alexander (24 August I820); 11. 385-86ob., draft note from the Russian government to the Spanish government concerning Spain's complaint.

26. Dodolev dates the note to Cea Bermúdez to 2 May 1820 (NS), the date it was transmitted. Austria, Britain, France, and Prussia all reacted negatively to the Russian memorandum describing the exchange of notes. Dodolev, Rossiia i Ispaniia, I7I-79. When Cea Bermúdez reported to the Spanish government, he expressed approval of the Russian note. The chargé d'affaires emphasized Alexander's unchanged support for liberal constitutions, as long as they emanated from the free sanction of "legitimate Princes." In other words, the monarch did not oppose the $18 \mathrm{I} 2$ constitution, but the illegal event "that preceded its promulgation." RGADA, f. I5, op. I, d. 377, Papers of Kapodistrias, 11. I07-21ob., unsigned report to the Spanish ministry concerning negotiations with the Russian government (probably written by Cea Bermúdez); VPR, v. 3 (II), annotation (20 April/2 May I820), p. 357, note from Nesselrode to Cea Bermúdez.

27. The version of the memorandum found in RGADA is dated $18 / 30$ April 1820 . RGADA, f. I5, op. I, d. 279, 1l. 193-202, memorandum sent to the ministers of H. I. M. for communication to foreign courts (I8 April I820). See also $V P R$, v. 3 (II), annotation (19 April/ı May I820), p. 357, memorial memorandum from the Russian cabinet to Austria, Britain, Prussia, and France.

28. The constitution of $18 \mathrm{I} 2$ envisioned a liberal nation state based on legal equality and proportional taxation, severely limited executive power, limits on the authority and property of the church, and the establishment of strong property rights, including freedom of enclosure. Carr, "Spain and Portugal," 443-47. 
29. Emperor Alexander's "thoughts" on the Spanish crisis were sent out as instructions to Russia's diplomats abroad and also transmitted to the courts of Vienna, London, Paris, and Berlin. Collective allied discussion of the Spanish crisis did not materialize before the Verona conferences of $\mathrm{I} 822$, and then only after multiple rebellions in Italy, Greece, and Portugal convinced the other powers of the need for a unified response.

30. RGADA, f. 3, op. I, d. 78, Reports and correspondence of Sturdza to Kapodistrias, 11. 352-54ob., account of Sturdza's official correspondence from I 4 November I8I9 to I2 December 1820.

31. RGADA, f. 3, op. I, d. 78, 11. 222-28ob., report from Sturdza to Kapodistrias ( 24 April I820).

32. RGADA, f. 3, op. I, d. 78, 1l. 352-54ob., account of Sturdza's official correspondence from I4 November I8I9 to I2 December I82O.

33. RGADA, f. 3, op. I, d. 78, 11. 222-28ob., report from Sturdza to Kapodistrias (24 April I820).

34. RGADA, f. 3, op. I, d. 78, 11. 352-54ob., account of Sturdza's official correspondence from 14 November 1819 to I2 December 1820.

35. $V P R$, v. 3 (II), doc. II 8 (2/14 May I820), pp. 371-74, Pozzo di Borgo to Nesselrode.

36. AVP RI, f. 133, op. 468, d. 2992, Doklady, 11. 258-6I, report from Nesselrode to Alexander summarizing dispatches received from Madrid via France (20 July 1820).

37. William Spence Robertson, "Russia and the Emancipation of Spanish America, 1816-1826," Hispanic American Historical Review 21, no. 2 (May 194I): 196-221; Norman Saul, Distant Friends: The United States and Russia, $1763-1867$ (Lawrence: University Press of Kansas, 1991), 80-83; Bartley, Latin American Independence, chap. 6.

38. VPR, v. 2 (I0), doc. 2 (2/14 October 1817), pp. I0-13, Tatishchev to Nesselrode. In October $18 \mathrm{I} 8$, Nesselrode described the British proposals as "more harmful than useful to Spain." VPR, v. 2 (I0), doc. 158 (not earlier than $13 / 25$ October I8I8), pp. 522-24, memorandum from Nesselrode to Alexander concerning discussions held in Aix-la-Chapelle on the mediation between Spain and its colonies.

39. See the protocol signed in Aix-la-Chapelle by Metternich, Richelieu, Castlereagh, Wellington, Hardenberg, Bernstorff, Nesselrode, and Kapodistrias. VPR, v. 2 (Io), doc. I73 (Io/22 November I8I8), pp. 588-89, protocol of the meeting of the plenipotentiaries of Russia, Austria, Britain, Prussia, and France.

40. $V P R$, v. 2 (Io), doc. 158 (not earlier than $13 / 25$ October 1818 ), pp. $522-24$, memorandum from Nesselrode to Alexander concerning discussions held in Aix-la-Chapelle on the mediation between Spain and its colonies. See also VPR, v. 2 (Io), doc. 159 (20 October/I November I818), pp. 525-31, report from Kapodistrias to Alexander; doc. 170 (9/21 November 1818), p. 583, Alexander to Ferdinand VII; doc. I72 (9/21 November I8I8), pp. 585-88, instruction from Nesselrode to Tuyll. See also, Robertson, "Russia and the Emancipation of Spanish America," 206-7.

4I. VPR, v. 2 (I0), doc. 177 (10/22 December I818), pp. 596-98, Alexander to Ferdinand VII. 
42. Historians date Ferdinand's explicit rejection of foreign intervention to December. Robertson, "Russia and the Emancipation of Spanish America," 206-7; Saul, Distant Friends, 87; Bartley, Latin American Independence, chap. 6.

43. $V P R$, v. 2 (10), doc. 179 (13/25 December 1818), pp. 602-10, Kapodistrias to Tatishchev.

44. Historians now recognize that Britain's opposition to intervention did not constitute opposition in principle (exactly the view of Alexander and his diplomatic agents). Rather, intervention should be carried out by interested parties on "a case-by-case basis" (exactly what had transpired in the Kingdom of the Two Sicilies and later in Spain). Wolfram Siemann, Metternich: Strategist and Visionary, trans. Daniel Steuer (Cambridge, MA: Harvard University Press, 2019), Kindle edition, 618-21.

45. VPR, v. 2 (I0), doc. 185 (19/31 January 1819), pp. 639-45, Tatishchev to Nesselrode. 46. An illustration of this tactic can be found in $V P R$, v. 2 (IO), doc. 185 (19/3I January 1819), pp. 639-45, Tatishchev to Nesselrode.

47. $V P R$, v. 2 (Iо), doc. 185 (19/31 January 1819), pp. 639-45.

48. $V P R$, v. 2 (I0), doc. 190 (30 January/II February I8I9), pp. 656-6I, Tatishchev to Alexander.

49. $V P R$, v. 2 (I0), doc. 19I (3I January/12 February I819), pp. 662-76, Tatishchev to Nesselrode.

50. The conditions for allied mediation enumerated by Britain included amnesty for the insurgents, neutrality on the part of the mediators, the suspension of hostilities, and the future independence of the colonies' commercial relations.

5I. The Russian view held that a Spanish government morally supported by the five great powers would be better positioned to convince the Spanish American insurgents that promised reforms could be implemented. In other words, the moral force of allied unity would be more effective in promoting acceptance of Ferdinand VII's authority. $V P R$, v. 2 (I0), doc. I85 (19/31 January I819), pp. 639-45, Tatishchev to Nesselrode.

52. VPR, v. 2 (IO), doc. 201 (19/3I March I819), pp. 704-5, Tatishchev to Nesselrode; doc. 202 (25 March/6 April 1819), pp. 705-7, confidential letter from Tatishchev to Spain's minister of foreign affairs Casa Irujo; doc. 203 (28 March/9 April I819), pp. 707-10, Pozzo di Borgo to Nesselrode.

53. On the proposed treaty between Spain and Portuguese Brazil, see VPR, v. 2 (Iо), n. 263 , p. 824 ; n. 278 , pp. $830-32$.

54. $V P R$, v. 2 (IO), doc. 204 (3I March/12 April I819), pp. 7 IO-I2, circular dispatch from Nesselrode to Lieven, Golovkin, Alopeus, and Pozzo di Borgo. See the communication to Tatishchev of the same date, also approved by Alexander and sent to Alopeus, Golovkin, Lieven, and Pozzo di Borgo: VPR, v. 2 (IO), doc. 208 (3I March/ı2 April I819), pp. 722-24, Nesselrode to Tatishchev.

55. $V P R$, v. 2 (Iо), doc. 208 (31 March/12 April I819), pp. $722-24$.

56. Michael Broers, "The Quest for a 'Juste Milieu': The Restoration as a Silver Age?” in Mächtepolitik und Friedenssicherung. Zur politischen Kultur Europas im Zeichen des Wiener Kongresses, ed. Reinhard Stauber, Florian Kerschbaumer, and Marion Koschier (Berlin: LIT Verlag, 2014), 33-46. 
57. VPR, v. 3 (II), doc. 75 (3I December I8I9/I2 January I820), pp. 215-I8, Tatishchev to Ferdinand VII.

58. RGADA, f. I5, op. I, d. 377, Papers of Kapodistrias, 11. 45-106ob. This memorandum is preserved among the papers of Kapodistrias, though its authorship is not specified.

59. RGADA, f. I5, op. I, d. 377, 11. 38-44. For the attribution, see Dodolev, Rossiia $i$ Ispaniia, 176-77.

60. As early as I8II, the Russian periodical press described the disintegration of the Spanish Empire due to revolution and civil war. Diplomats likewise reported on the success of the independence movements in Spanish America, and by 1814 Tatishchev expected Spanish American independence. Robertson, "Russia and the Emancipation of Spanish America," 209-12; Bartley, Latin American Independence, chap. 5.

6r. VPR, v. 3 (II), doc. 216 (2/14 February I821), pp. 712-15, Nesselrode to Bulgari.

62. As early as $3 / 15$ July 1820 the French government recognized the need for a common allied response to the crisis in Spain. In light of British opposition to collective action, French and Russian diplomats discussed the possibility of a common instruction (not necessarily an official communication) to regulate the language that allied agents would use to discuss their respective positions on Spain. The basis of the instruction would be the legitimacy and integrity of the Spanish monarchy, though decisions about the forms of government would be left to the king and his associates. AVP RI, f. 133, op. 468, d. 2992, Doklady, 11. 256-57, dispatch from Pozzo di Borgo concerning the French government's memorandum on Spain to be communicated to the Russian government by Count La Ferronnays (3/15 July i820).

63. Prior to the disorders there had been talk of modifying the constitution to limit the franchise and enhance the king's power.

64. Gonzalo Butrón Prida, "From Hope to Defensiveness: The Foreign Policy of a Beleaguered Liberal Spain, I820-I823," English Historical Review I33, no. 562 (June 2018): 567-96, here 573-85. See also Charles K. Webster, The Foreign Policy of Castlereagh, I815-1822. Vol. 2: Britain and the European Alliance (London: G. Bell, 1963). Starting in October 1820, Ferdinand repeatedly appealed to the allies to save his kingdom and family. Stites, Four Horsemen, location 2265-2372; Dodolev, Rossiia i Ispaniia, 183-84; Schroeder, Transformation, 62I-28. For a royalist account of the threat to Ferdinand VII and his family, see the mémoire of I December I820 (NS) addressed to Alexander by the chevalier de Mésiére. RGADA, f. I5, op. I, d. 290.

65. AVP RI, f. I33, op. 468, d. I1853, Vienna and Verona (I822), t. I, ll. 4-IIob., acts of the conferences of Verona on the affairs of Spain. The mémoire of de Mésiére likewise reported on a military build-up by Spanish and Portuguese revolutionaries, that threatened all legitimate governments and sovereigns. RGADA, f. I5, op. I, d. 290.

66. Some Russian diplomats explicitly stated that processes of change could not be controlled and that the revolutionary tempest had to play out. AVP RI, f. 133, op. 468 , d. 2992, Doklady, 11. 163-60ob., "Reflections on the Current State of Europe" (8 April I820) sent as a mémoire to Kapodistrias from Prince Dmitrii Dolgorukii.

67. AVP RI, f. I33, op. 468, d. II853, t. I, 1l. 37-39ob., 134-35ob., proposals of Austria presented at the conferences of $3 \mathrm{I}$ October 1822. 
68. AVP RI, f. 133, op. 468, d. I1853, t. I, 11. 136-37, response of Russia's plenipotentiaries to the proposals of Austria presented at the conferences of ${ }_{31}$ October (2I October $/ 2$ November 1822); VPR, v. 4 (I2), doc. 205 (21 October/2 November I822), pp. 588-89, declaration of Russia's plenipotentiaries in response to Austria's proposals of $3 \mathrm{I}$ October.

69. AVP RI, f. 133, op. 468, d. 11853, t. I, 11. 2-20b., I08-I2, coup d'oeil on the question of Spain (I5 November I822).

70. AVP RI, f. 133, op. 468, d. I1853, t. I, 11. 49-490b., 173-740b.; t. II, 11. 97-970b., verbal proceedings signed by the plenipotentiaries of Austria, France, Prussia, and Russia (19 November I822); VPR, v. 4 (I2), doc. 206 (7/19 November I822), pp. 590-91, protocol signed by the plenipotentiaries of Russia, Austria, Prussia, and France.

71. AVP RI, f. 133, op. 468, d. 11853, t. I, 11. 47-48ob., précis of the conferences of I8, I9, 20 November; $V P R$, v. 4 (I2), doc. 209 (14/26 November I822), pp. 594-96, Nesselrode to Bulgari; doc. 210 (I4/26 November I822), pp. 596-99, Nesselrode to Bulgari.

72. AVP RI, f. I33, op. 468, d. I1853, t. I, 11. 50-58ob.; t. II, 11. 56-58ob., dispatch to Bulgari approved in Verona 9/21 November 1822 and signed $14 / 26$ November $1822 ; V P R$, v. 4 (I2), annotation (I $4 / 26$ November I822), p. 594, protocol signed by the plenipotentiaries of Russia, Austria, Prussia, and France.

73. On 7 July 1822 the Royal Guard revolted and marched on Madrid, though it was unclear whether they sought to modify the constitution or restore absolutism. The Cortes repressed the revolt, the king broke with Riego, and civil war ensued. The king also continued to complain to foreign envoys that he had become enslaved. Stites, Four Horsemen, location 2211-2372.

74. AVP RI, f. I33, op. 468, d. II853, t. I, ll. 59-620b., dispatch to Bulgari; VPR, v. 4 (I2), doc. 209 (I4/26 November I822), pp. 594-96, Nesselrode to Bulgari.

75. France did not adhere to the same sequence of actions, and in a December communication to Pozzo di Borgo, Nesselrode expressed concern about the French commitment to act in Spain. At the same time, he affirmed the intention of Austria, Prussia, and Russia to break relations with Spain. $V P R$, v. 4 (I2), doc. 214 (2/14 December I822), pp. 607-II, Nesselrode to Pozzo di Borgo.

76. Prida, "From Hope to Defensiveness," 584-96; Stites, Four Horsemen, location 2510-2724; Schroeder, Transformation, 621-28; Dodolev, Rossiia i Ispaniia, 166-93; Bartley, Latin American Independence, location 297I-3206.

77. AVP RI, f. I33, op. 468, d. II853, t. I, 11. 457-67, circular on Italian affairs to be sent by the courts of Russia, Austria, and Prussia to their diplomatic agents as a common instruction (2/1 4 December 1822), unsigned lithographic copy; $V P R$, v. 4 (I2), annotation (2/14 December I822), p. 607, circular from the governments of Russia, Austria, and Prussia to their representatives abroad; n. 289, pp. 719-24.

78. See also VPR, v. 4 (I2), doc. 2 II (2 December I822), pp. 600-3, protocol of the meeting of the plenipotentiaries of Russia, Austria, and Prussia with the participation of the plenipotentiary of the Sardinian kingdom; annotation (20 November/2 December I822), p. 603, convention concluded by Russia, Austria, and Prussia with the Sardinian kingdom on the timetable for withdrawal of the Austrian auxiliary corps. 
79. See also $V P R$, v. 4 (12), annotation (8 December 1822), p. 604, protocol of the meeting of the plenipotentiaries of Russia, Austria, Prussia, and the Kingdom of the Two Sicilies; annotation (9 December I822), p. 605, protocol of the confidential meeting of the plenipotentiaries of Russia, Austria, Britain, Prussia, and the Kingdom of the Two Sicilies.

80. AVP RI, f. I33, op. 468, d. I1853, t. I, 1l. 457-67, circular on Italian affairs to be sent by the courts of Russia, Austria, and Prussia to their diplomatic agents as a common instruction (2/14 December I822). Despite the apparent finality of the Verona circular, the allies remained concerned about ongoing revolutionary activity in Italy: $V P R$, v. 4 (I2), annotation (II December I822), p. 607, declaration of the Russian, Austrian, and Prussian courts.

8I. AVP RI, f. 133, op. 468, d. II 853, t. I, 11. 457-67, circular on Italian affairs to be sent by the courts of Russia, Austria, and Prussia to their diplomatic agents as a common instruction (2/14 December 1822).

82. AVP RI, f. 133, op. 468, d. I1853, t. I, 11. 457-67, circular on Italian affairs.

83. Humphreys, "Emancipation of Latin America," 6r2-38. On Russia's continuing hope for reconciliation between the Spanish colonies and the metropolis, see $V P R$, v. 4 (I2), annotation (24 October I822), p. 587, record of the conversation between the French minister of foreign affairs Montmorency and Alexander.

84. For recent analysis and summary of ongoing debates, see O'Meara, Russian Nobility, chap. I2.

85. Eric Hobsbawm, The Age of Revolution, $1789-1848$ (New York: Vintage Books, 1996).

86. Osterhammel describes the European system of states as "an action-guiding image in the heads of the foreign policy elites of individual countries.” Jürgen Osterhammel, The Transformation of the World: A Global History of the Nineteenth Century, trans. Patrick Camiller (Princeton, NJ: Princeton University Press, 20I4), Kindle edition, location I1996-I2003.

87. According to Osterhammel, between 1853 and I871 five wars involving the great powers shattered the post-Vienna cohesion among European states: the Crimean War (1853-56), France and Sardinia-Piedmont versus Austria (I859), Denmark versus Prussia (I864), Austria versus Prussia (I866), and France versus Prussia (1870-7I). Osterhammel, Transformation of the World, location I2003-I2085.

\section{Conclusion: Russia's European Diplomacy}

I. James Van Horn Melton, The Rise of the Public in Enlightenment Europe (Cambridge: Cambridge University Press, 200I).

2. Dominic Lieven, Russia against Napoleon: The True Story of the Campaigns of War and Peace (New York: Penguin Books, 2009).

3. VPR, v. 2 (Io), doc. 83 (I5/27 March I8I8), pp. 265-68, Golovkin to Kapodistrias. Emperor Alexander also expressed satisfaction with the meetings between Golovkin 
and Metternich in the spring of $1818 . V P R$, v. 2 (I0), doc. 104 (19 April/i May 1818), pp. 334-36, Kapodistrias to Metternich; doc. IIo (2/14 May I818), pp. 354-58, Golovkin to Kapodistrias.

4. $V P R$, v. 2 (10), doc. 96 (4/16 April I818), pp. 297-304, Golovkin to Kapodistrias. On the oligarchic tendency, see the objections raised by Bavaria, Hanover, and the Netherlands in connection with the meeting of the great powers in Aix-la-Chapelle. $V P R$, v. 2 (I0), doc. II2 (6/18 May 1818), pp. 364-67, Lieven to Kapodistrias.

5. The communication from Alexander preserved in RGADA is dated 9/2I November I8I 8 and addressed to Christoph Lieven. RGADA, f. I5, op. I, d. 284, On the establishment of the Holy Alliance, 1l. II-I2ob.

6. VPR, v. 2 (10), doc. 108 (22 April/4 May I818), pp. 350-51, Pahlen to Nesselrode.

7. For this distinction, see $V P R$, v. 2 (Iо), doc. I85 (19/31 January 1819), pp. 639-45, Tatishchev to Nesselrode.

8. For perceptive analysis of the reinvented "old regime" in the Restoration era, see Ambrogio A. Caiani, "Re-inventing the Ancien Régime in Post-Napoleonic Europe," European History Quarterly 47, no. 3 (2017): 437-60.

9. $V P R$, v. 2 (I0), doc. 94 (27 March/8 April I818), pp. 292-93, Kapodistrias to Lieven; v. 3 (II), doc. 197 (29 November/I I December I820), pp. 645-47, Nesselrode to Struve.

Io. $V P R$, v. 2 (Iо), doc. 8I (2/14 March I818), pp. 263-64, Pahlen to Nesselrode. Russia's diplomats received instructions forbidding them to comment on constitutional debates in German states. On Bavaria in particular, see VPR, v. 3 (II), doc. 67 (30 November/ı2 December I819), pp. 190-92, Nesselrode to Pahlen.

II. AVP RI, f. I33, op. 468, d. 2992, Doklady, 1l. 366-67ob., report from Nesselrode to Alexander (17 September I820). For Alexander's speech at the opening of the Polish Diet on 27 March I818, see Le Conservateur impartial, no. 26 (29 March/ı April I818): II3-I5. The speech described the Polish Diet as a model for Russia and has been read by contemporaries and subsequent generations as a promise of further constitutional reform.

I2. Throughout the nineteenth-century, high-level Russian officials developed projects for political reform, including constitutional reform, though none came to fruition. Historians likewise point out that the provisions of the Polish constitution were never fully implemented. Marc Raeff, ed., Plans for Political Reform in Imperial Russia, 1730Igos (Englewood Cliffs, NJ: Prentice-Hall, 1966); S. Bertolissi, A. N. Sakharov, and A. N. Medushevskii, eds., Konstitutsionnye proekty v Rossii XVIII-nachalo XXv. (Moscow: Institut rossiiskoi istorii RAN, 2000). For recent coverage of constitutionalist thinking in the reign of Alexander, see Patrick O'Meara, The Russian Nobility in the Age of Alexander I (London: Bloomsbury Academic, 2019,) 155-60. On Alexander's continuing interest in reform, see S. V. Mironenko, Aleksandr i dekabristy: Rossiia v pervoi chetverti XIX veka. Vybor puti (Moscow: Kuchkovo pole, 2017).

I3. $V P R$, v. 2 (I0), doc. 33 (6/18 December 1817), pp. 104-9, Nesselrode to envoy in Dresden Khanykov. On the importance of impartiality, see also $V P R$, v. 2 (Iо), doc. 47 (I2/24 January I818), pp. I54-56, Nesselrode to Pahlen. 
I4. Elise Kimerling Wirtschafter, Social Identity in Imperial Russia (DeKalb: Northern Illinois University Press, 1997), chap. I; Elise Kimerling Wirtschafter, “The Ideal of Paternalism in the Pre-Reform Army," in Imperial Russia, I700-I9I7: State, Society, Opposition, ed. Ezra Mendelsohn and Marshall S. Shatz (DeKalb: Northern Illinois University Press, 1988), 95-II4.

I5. It is useful here to recall Adam Smith's theory of empathy and moral sentiment. See Jerry Z. Muller, Adam Smith in His Time and Ours: Designing the Decent Society (New York: The Free Press, 1993).

I6. $V P R$, v. 2 (IO), doc. 48 (I2/24 January I8I8), pp. I56-58, rescript from Alexander to Golovkin.

17. $V P R$, v. 2 (10), doc. 49 (14/26 January I8I8), pp. 158-67, memorandum of instruction from the Ministry of Foreign Affairs to Golovkin, on special mission in Vienna.

18. The secret alliance against Prussia and Russia arose from Austrian, British, and French efforts to thwart Alexander's policy on the Polish-Saxon question.

19. $V P R$, v. 2 (I0), doc. 49 (I4/26 January I8I8), pp. 158-67, memorandum of instruction to Golovkin.

20. One should note here that in the dispute over Poland at the Congress of Vienna, the personal friendship between Frederick William III and Alexander I translated into a Prussian refusal to enter into agreements designed to block Russia's plans.

2I. $V P R$, v. 2 (IO), doc. 84 (I5/27 March I818), pp. 268-7I, Golovkin to Kapodistrias.

22. $V P R$, v. 2 (10), doc. II2 (6/18 May I818), pp. 364-67, Lieven to Kapodistrias.

23. $V P R$, v. 2 (I0), doc. I87 (25 January/6 February I8I9), pp. 647-49, circular dispatch from Nesselrode to Russia's diplomatic representatives abroad.

24. VPR, v. 3 (II), doc. 43 (4/16 October I8I9), pp. 134-35, Alexander to Francis I; doc. 44 (6/18 October I819), pp. 136-37, Kapodistrias to Alopeus.

25. AVP RI, f. I33, op. 468, d. 2992, Doklady, 11. 395-97, 405-10, report from Nesselrode and Kapodistrias to Alexander concerning Austria's analysis of how the allies should respond to the revolution in Naples and the Austrian proposal for a treaty of guarantee presented in Troppau (I5 October 1820).

26. The harmful German universities included Giessen, Heidelberg, and Jena. The acts of the Committee of Ministers identified the students as Livonians, Estonians, and Courlanders. Alexander's decision is dated II $/ 23$ November 1820 and addressed to Count Kochubei. AVP RI, f. I33, op. 468, d. 2990, Doklady, 11. 79-82, project for a dispatch approved by Alexander.

27. Alexander believed that because the Karlsbad Decrees had proven effective in Prussia and Hanover, it would be inappropriate to issue an explicit decree ordering the students to return home. Conditions had improved in Germany over the past two years, and persuasion should be sufficient to achieve the desired outcome.

28. Jonathan Israel, Enlightenment Contested: Philosophy, Modernity, and the Emancipation of Man, I679-1752 (New York: Oxford University Press, 2006). For the Russian case, see Elise Kimerling Wirtschafter, Religion and Enlightenment in Catherinian Russia: The Teachings of Metropolitan Platon (DeKalb: Northern Illinois University Press, 
2013). On "human flourishing," see Charles Taylor, A Secular Age (Cambridge, MA: Harvard University Press, 2007); Charles Taylor, Sources of the Self: The Making of the Modern Identity (Cambridge, MA: Harvard University Press, 1989).

29. These include, among others: the reconciliation of "great power demands for influence and control with small-power requirements for independence"; the role of intermediary bodies or independent smaller states and territories in buffering, separating, and connecting great powers; the development of rules and concepts for cooperation and concert between the powers; ways to guarantee "the rights and status of all states while discriminating between their different functions and responsibilities, necessarily conditioned by divergent capacities and interests"; the idea of "a political equilibrium based on the tacit acceptance by smaller powers of a general great-power hegemony so long as their independence and rights were guaranteed"; innovative regulation of diplomatic precedent and procedure; abolition of the slave trade; and international regulation and navigation of waterways. See Paul W. Schroeder, The Transformation of European Politics $1763-1848$ (New York: Oxford University Press, 1994), 575-82.

30. Lieven, Russia against Napoleon.

31. AVP RI, f. 133, op. 468, d. 2992, Doklady, 11. 395-97, report from Nesselrode and Kapodistrias to Alexander concerning Austria's analysis of how the allies should respond to the revolution in Naples (is October I820).

32. RGADA, f. I5, op. I, d. 377, Papers of Kapodistrias, 11. 107-2 10b., unsigned communication from April I820 located in a subsection titled "Ministère Espagnol"; appears to be written by the Spanish envoy Cea Bermúdez and addressed to his government.

33. Later variants include Slavophile, Pan-Slav, and Eurasianist thought.

34. For statements acknowledging the inevitability of revolutionary change, see AVP RI, f. I33, op. 468, d. 2992, Doklady, 1l.163-69ob., letter and memorandum of Prince Dmitrii Dolgorukii to Kapodistrias (8 April I820); 11. 405-10, report from Nesselrode and Kapodistrias to Alexander concerning Austria's proposal for a treaty of guarantee (15/27 October I820). 